\title{
Pedogenesis in a Pleistocene fluvial system of the Northern Pantanal - Brazil
}

\author{
Alexandre F. Nascimento a, Sheila A.C. Furquim ${ }^{\text {b }}$, Robert C. Graham ${ }^{\text {c }}$, Raphael M. Beirigo ${ }^{\text {d }}$, \\ Jairo C. Oliveira Junior ${ }^{\mathrm{e}}$, Eduardo G. Couto ${ }^{\mathrm{f}}$, Pablo Vidal-Torrado ${ }^{\mathrm{g}, *}$ \\ a Embrapa Agrossilvipastoril, Sinop, MT, Brazil \\ b Departamento de Ciências Exatas e da Terra, Universidade Federal de São Paulo, Diadema, Brazil \\ c Soil \& Water sciences program, Department of environmental science, University of California, Riverside, USA \\ d Centro de Ciências e Tecnologia Agroalimentar, Universidade Federal de Campina Grande, Pombal, Brazil \\ e Departamento de Agronomia, Universidade Tecnológica Federal do Paraná, Dois Vizinhos, Brazil \\ ${ }^{\mathrm{f}}$ Departamento de Solos e Engenharia Rural, Universidade Federal de Mato Grosso, Cuiabá, Brazil \\ g Departamento de Ciência do Solo, Universidade de São Paulo, Piracicaba, Brazil
}

\section{A R T I C L E I N F O}

\section{Article history:}

Received 22 January 2015

Received in revised form 17 April 2015

Accepted 19 April 2015

\section{Keywords:}

Soil genesis

Wetland soils

São Lourenço fluvial fan

Termite activities

Mound

\begin{abstract}
A B S T R A C T
Sedimentology and hydrology seem to play a predominant role in soil formation in the Pantanal, since the fluvial systems of this wetland provided Quaternary sediments and shaped the landscape. However, pedogenic processes are active in this region mainly due to the floods that occur during the summer and fall season. The goal of this work was to study the pedogenesis in a representative transect on the São Lourenço fluvial fan, which has an area of about $16,000 \mathrm{~km}^{2}$ and is one of the largest sedimentary compartments of the Northern Pantanal, West Central Brazil. A transect of $125 \mathrm{~m}$ was studied in the late Pleistocene sedimentary lobe of the fluvial fan, where four landform elements were identified (paleo-channel, paleo-levee, paleo-floodplain and mound) and described to show the soil horizon boundaries along the landform unit. Samples were collected from trenches, auger holes, and boreholes, and were analyzed for soil description and characterization. Soil analyses carried out were: macroand micromorphological, physical, chemical, mineralogical, $\mathrm{C}$ isotope fractionation, and OSL dating analyses. The set of evidence shows that the studied transect originated from Pleistocene sediments due to the activity of the São Lourenço fluvial fan. The following soil-landform element relationships developed: Quartzipsamments in the paleo-channel; Plinthaquults in the paleo-levee and paleo-floodplain and; Natrustalfs in the mound. Evidences of pedogenic processes in the transect are: a) clay eluviation and illuviation, resulting in formation of the Bt horizon in the soils at the lower part of the transect and mound; b) gleization and plinthization, mainly at the lower part of the transect, resulting in formation of mottles, reduced soil matrix, and nodules (plinthite and petroplinthite); c) bioturbation, responsible for addition of materials at the soil surface, assisting in the formation/maintenance of the mound; and d) the sodium concentration, observed in soils that have higher clay contents, which are highest in the mound has the highest levels.
\end{abstract}

(C) 2015 Elsevier B.V. All rights reserved.

\section{Introduction}

Among the soil-forming factors, the parent material seems to play a predominant role in the Pantanal. The fluvial systems of this wetland have provided Quaternary sediments and shaped the landscape (Assine and Silva, 2009). There are several active fluvial systems in this area, including fluvial plains, fluvial fans and lakes, that are responsible for the landforms and most of the sediments deposited on the wetland (Assine

\footnotetext{
* Corresponding author.

E-mail addresses: alexandre.nascimento@embrapa.br (A.F. Nascimento) sfurquim@unifesp.br (S.A.C. Furquim), robert.graham@ucr.edu (R.C. Graham), rmbeirigo@yahoo.com.br (R.M. Beirigo), jairo@agronomo.eng.br (J.C. Oliveira Junior), egcouto@gmail.com (E.G. Couto), pvidal@usp.br (P. Vidal-Torrado).
}

et al., 2014; Assine and Silva, 2009). Among these fluvial systems, the fluvial fans predominate, with at least ten of them contributing sediments for the whole area of the Pantanal (Assine and Silva, 2009).

Fluvial fans are distributary depositional systems characterized by the frequent construction and abandonment of the main channel of the river (Nichols and Fisher, 2007). This abandonment may occur due to a process known as avulsion, defined as a shift in the main channel bed of the river to a new gradient, which leads the water course to flow through the old fluvial plain (Mackey and Bridge, 1995). Within this system, sedimentary lobes with different ages may be found, showing sedimentological and geomorphological peculiarities that allow them to be distinguished (Nichols and Fisher, 2007).

In the São Lourenço fluvial fan, Northern Pantanal, both Pleistocene and Holocene lobes have been identified (Assine et al., 2014; Corradini 
and Assine, 2012). Pleistocene lobes show advanced stages of erosion compared to Holocene lobes (Corradini and Assine, 2012; Nascimento, 2012). Pleistocene channels and floodplains have geomorphologic features and sedimentary architecture that reflect a depositional system with less lateral migration of the river channels and sediments with lower clay contents than Holocene floodplains (Nascimento, 2012). Another peculiarity of the Pleistocene floodplains is the occurrence of mounds. These mounds are rounded relief features about $1 \mathrm{~m}$ higher than the paleo-floodplain and $15 \mathrm{~m}$ in diameter, with woody plants as the main vegetation. Mound formation in the Pantanal can be attributed to (i) buildup by mound-building social insects; or (ii) differential erosion, with mounds corresponding to remnants of an original surface (Oliveira-Filho, 1992; Renard et al., 2012).

The influence of the depositional system on soil distribution in the Pantanal is remarkable since there is a close relationship between soils and landforms: Quartzipsamments are associated with paleo-channels; Natrustalfs and Albaqualfs with paleo-levees and mounds; and Aquents, Aquepts, Plinthaquults, and Fluvaquentic Inceptisols are associated with paleo-floodplains (Nascimento, 2012). Although the fluvial system exerts direct influence on the soil formation, such as on Quartzipsamments and Fluvaquents, pedogenic processes are active mainly due to the floods that occur during the summer and fall seasons in the Pantanal (Girard et al., 2010). The floods trigger soil reactions that produce redoximorphic features, such as a depleted matrix and redox concentrations (Vepraskas, 2001). Therefore, it is essential to study the soil-landscape relationships to understand soil distribution in the Pantanal. The impacts of soilforming processes on Quaternary sediments are important for understanding the past and future dynamics of these vulnerable systems (Winter, 2000).

To understand the soil formation processes in the Northern Pantanal and accounting for the dynamics of the fluvial fans, the goal of this work was to study the pedogenesis in a representative transect of the São Lourenço fluvial fan, one of the largest sedimentary compartments in that region (Assine et al., 2014).

\section{Material and methods}

\subsection{Study site and field methods}

The studied transect is on a Pleistocene lobe of the São Lourenço fluvial fan, Northern Pantanal, Mato Grosso state, West Central Brazil (Fig. 1).

The studied sedimentary lobe is between 125 and $135 \mathrm{~m}$ asl and has a slope gradient of $0.03^{\circ}$ in the direction NE-SW. Parts of the landscape are subject to seasonal floods and are covered by grasses, and slightly higher non-flooded spots have Cerrado vegetation. In general, flooded features are paleo-floodplains that have silt-clay sediments and nonflooded features are mounds and paleo-channels with sand sediments (Nascimento, 2012). These Quaternary sediments were transported by the São Lourenço River, which has Mesozoic and Paleozoic sedimentary rocks in most of its catchment area outside the Pantanal.

The regional climate, according to Köppen's classification, is tropical wet (Aw), with an average of $1200 \mathrm{~mm}$ of annual precipitation, rainy summers, dry winters, and monthly average temperatures between 22 and $32^{\circ} \mathrm{C}$. Floods in the sedimentary lobe occur mainly between January and June, while the non-flooded season lasts from June to December. Due to the local and regional rainfall and the high level of the rivers that drain the plain, the maximum flooding is observed in April/May (Girard et al., 2010).

In order to understand soil formation on this Pleistocene sedimentary lobe, a representative transect of $125 \mathrm{~m}$ was studied, chosen according to the soil map of the area (1:100,000 scale). Based on the satellite image (Fig. 2), the beginning of the transect was interpreted as a paleo-channel, and its terminus segment has the configuration of a mound. Given the natural complexity of the sedimentary environments, this transect was studied following the methodology of Boulet
(1988), which shows both lateral and vertical soil horizon boundaries along a landform unit. Thus, 30 auger holes were used to identify and characterize the soil horizons in the transect, thus revealing the best locations for more detailed examination using trenches. Six trenches were opened, 4 for complete soil description and sampling and 2 for the purpose of confirming soil horizon boundaries and sampling for dating analysis. The soils were described following Schoeneberger et al. (2002). Additional six boreholes were made for sedimentary characterization below the 2-m depth.

The studied transect was described from the higher to the lower portion. Its surface topography was measured using a hose level. Small samples of the soil horizons were placed in the order of their occurrence in small boxes, facilitating the observation of the lateral and vertical distribution of soil horizons and the establishment of their boundaries in the transect.

\subsection{Laboratory methods}

In order to carry out the particle-size, chemical, and mineralogical analyses, we sieved the soil through 2-mm-mesh sieves. The hydrometer method was used for particle-size analysis and the sands were classified into five fractions (very coarse sand: $2-1 \mathrm{~mm}$; coarse sand: $1-$ $0.5 \mathrm{~mm}$; medium sand: $0.5-0.250 \mathrm{~mm}$; fine sand: $0.25-0.10 \mathrm{~mm}$ and; very fine sand: $0.10-0.05 \mathrm{~mm}$ ) (Gee and Bauder, 1986). The $\mathrm{pH}$ was determined in water (potentiometer), using a soil:solution ratio of 1:2.5 after shaking and 1-hour rest. Exchangeable aluminum $\left(\mathrm{Al}^{3+}\right)$, potential acidity $(\mathrm{H}+\mathrm{Al})$, and exchangeable cations $\left(\mathrm{Ca}^{2+}, \mathrm{Mg}^{2+}, \mathrm{K}^{+}\right.$, and $\left.\mathrm{Na}^{+}\right)$ were determined as described by Embrapa (1997). The $\mathrm{Ca}^{2+}, \mathrm{Mg}^{2+}$ and $\mathrm{Al}^{3+}$ were extracted with $1 \mathrm{~mol} \mathrm{l}^{-1} \mathrm{KCl} ; \mathrm{P}, \mathrm{K}^{+}$and $\mathrm{Na}^{+}$with $0.0125 \mathrm{M}$ $\mathrm{H}_{2} \mathrm{SO}_{4}+0.05 \mathrm{M} \mathrm{HCl} ; \mathrm{H}+\mathrm{Al}$ with $0.5 \mathrm{M}$ calcium acetate at $\mathrm{pH}$ 7.0. Concentrations of $\mathrm{Ca}^{2+}$ and $\mathrm{Mg}^{2+}$ were determined by atomic absorption spectroscopy; $\mathrm{K}^{+}$and $\mathrm{Na}^{+}$by flame photometry; $\mathrm{Al}^{3+}$ and $\mathrm{H}+\mathrm{Al}$ by complexometric titration and $\mathrm{P}$ by colorimetry. The results of the chemical analyses allowed the calculation of the cation exchange capacity $\left[\mathrm{CEC}=\mathrm{Ca}^{2+}+\mathrm{Mg}^{2+}+\mathrm{K}^{+}+\mathrm{Na}^{+}+(\mathrm{H}+\mathrm{Al})\right]$, the sum of exchangeable base $\left(\mathrm{S}=\mathrm{Ca}^{2+}+\mathrm{Mg}^{2+}+\mathrm{K}^{+}+\mathrm{Na}^{+}\right)$, base saturation [V = $\left.\left(\mathrm{Ca}^{2+}+\mathrm{Mg}^{2+}+\mathrm{K}^{+}+\mathrm{Na}^{+}\right) \times 100 / \mathrm{CEC}\right]$, aluminum saturation $\left[\mathrm{m}=\mathrm{Al}^{3+} \times 100 /\left(\mathrm{Ca}^{2+}+\mathrm{Mg}^{2+}+\mathrm{K}^{+}+\mathrm{Na}^{+}+\mathrm{Al}^{3+}\right)\right]$, and exchangeable sodium saturation (ESP $=\mathrm{Na}^{+} \times 100 / \mathrm{CEC}$ ) (Embrapa, 1997).

Total carbon $(\mathrm{C})$, total nitrogen $(\mathrm{N})$, and carbon isotope $\left({ }^{13} \mathrm{C}\right)$ were determined using a dry combustion element analyzer (LECO ${ }^{8} \mathrm{CN}-$ 2000) coupled to a mass spectrometer (Carlo Elba ${ }^{\circledR}$, Delta Plus). For this purpose, soil samples were collected from the trenches at intervals of $5 \mathrm{~cm}$ from the surface to the $20 \mathrm{~cm}$ depth. Below $20 \mathrm{~cm}$, sampling was made by individual horizons or layers.

Undisturbed oriented soil samples were collected from representative horizons for micromorphological studies. The samples were collected, prepared and described according to Murphy (1986) and Bullock et al. (1985).

In selected sandy soil horizons, samples were collected in PVC tubes (diameter $50 \mathrm{~mm} \times$ length $200 \mathrm{~mm}$ ), which were identified and stored according to Sallun et al. (2007). The samples were dated using optically stimulated luminescence (OSL), by the single aliquot regeneration protocol (Murray and Wintle, 2000). Hence, four samples were analyzed in the Laboratory of Glass and Dating at FATEC (Faculdade de Tecnologia do Estado de São Paulo, Brazil).

Samples of 6 horizons (AP5 horizon C; AP8 horizon C; AP7 horizon E; AP7 horizon Btg; AP6 horizon AB; AP6 horizon Btgn) were analyzed by X-ray diffraction (XRD), according to Jackson (1979). About $30 \mathrm{~g}$ was weighed and organic matter and iron oxides were removed. Total sand, silt, and clay were then separated. Glass slides with oriented clay were subjected to the following treatments: $\mathrm{Mg}^{2+}$ at room temperature $\left(25^{\circ} \mathrm{C}\right) ; \mathrm{Mg}^{2+}$ solvated with ethylene glycol (EG); $\mathrm{K}^{+}$at room temperature $\left(25^{\circ} \mathrm{C}\right) ; \mathrm{K}^{+}$heated to $300{ }^{\circ} \mathrm{C}$; and $\mathrm{K}^{+}$heated to $500{ }^{\circ} \mathrm{C}$. 


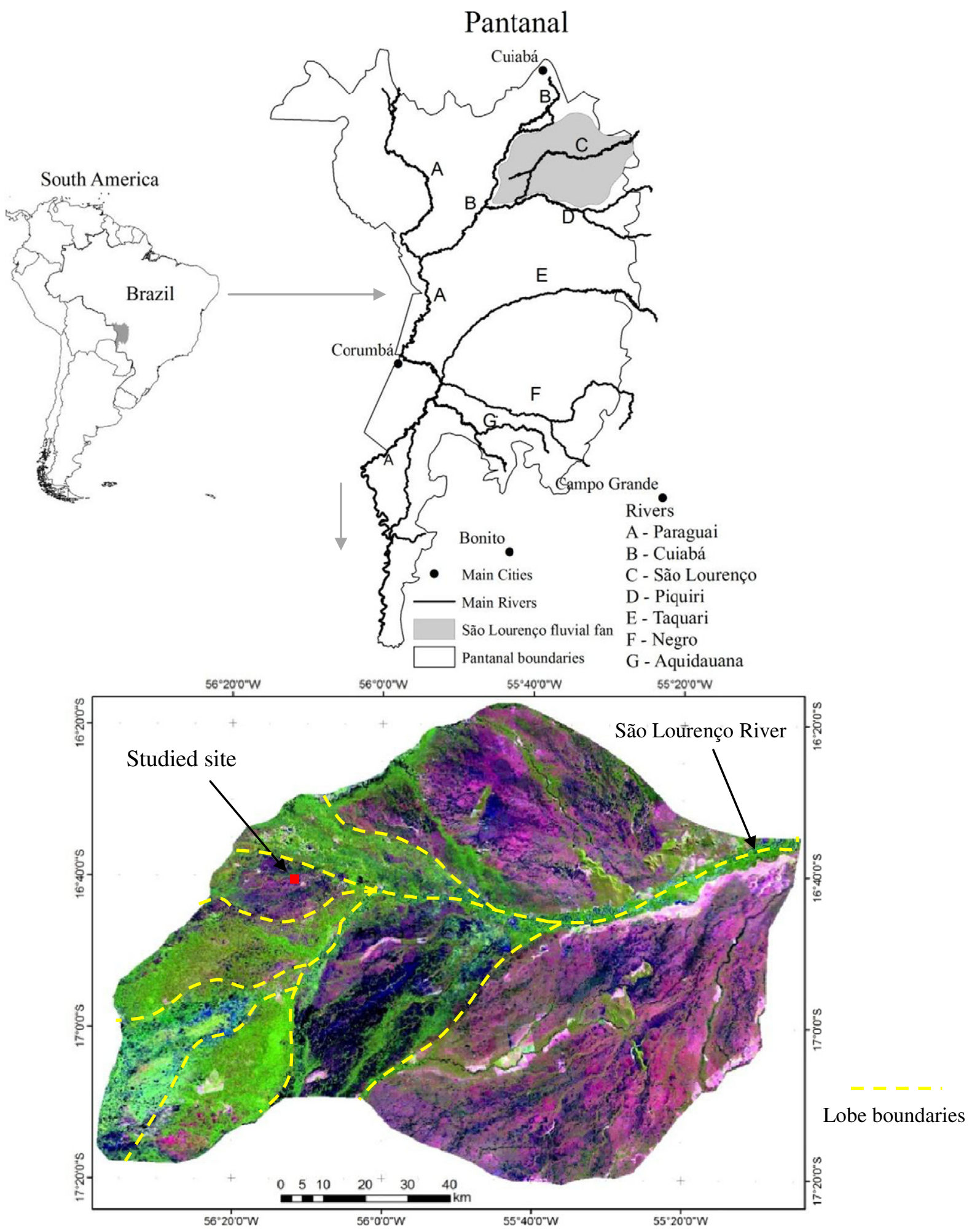

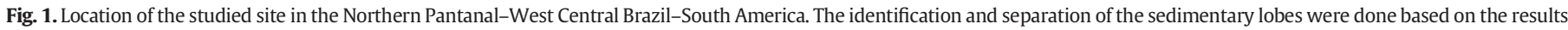
of Corradini and Assine (2012). LandSat5 imagery at the flood season (May, 1995).

These samples were irradiated from 3 to $35^{\circ} 2 \theta$ in an X-ray diffractometer, using a step size of $0.02^{\circ} 2 \theta$ and a counting time of $1 \mathrm{~s}$ per step, voltage of $35 \mathrm{kV}$ and a current $15 \mathrm{~mA}$. The sand and silt powder samples were irradiated from 5 to $70^{\circ} 2 \theta$, under the same conditions of step size, counting time, voltage, and current. A Rigaku MiniFlex II diffractometer was used, with copper ( $\mathrm{CuK} \alpha)$ radiation and a graphite crystal monochromator.

The XRD peaks of the clay treated with $\mathrm{Mg}^{2+}$ and EG were separated using Lorentzian shapes. The peak areas of the clays were used to determine the relative abundance of clay types present in the soil matrix 


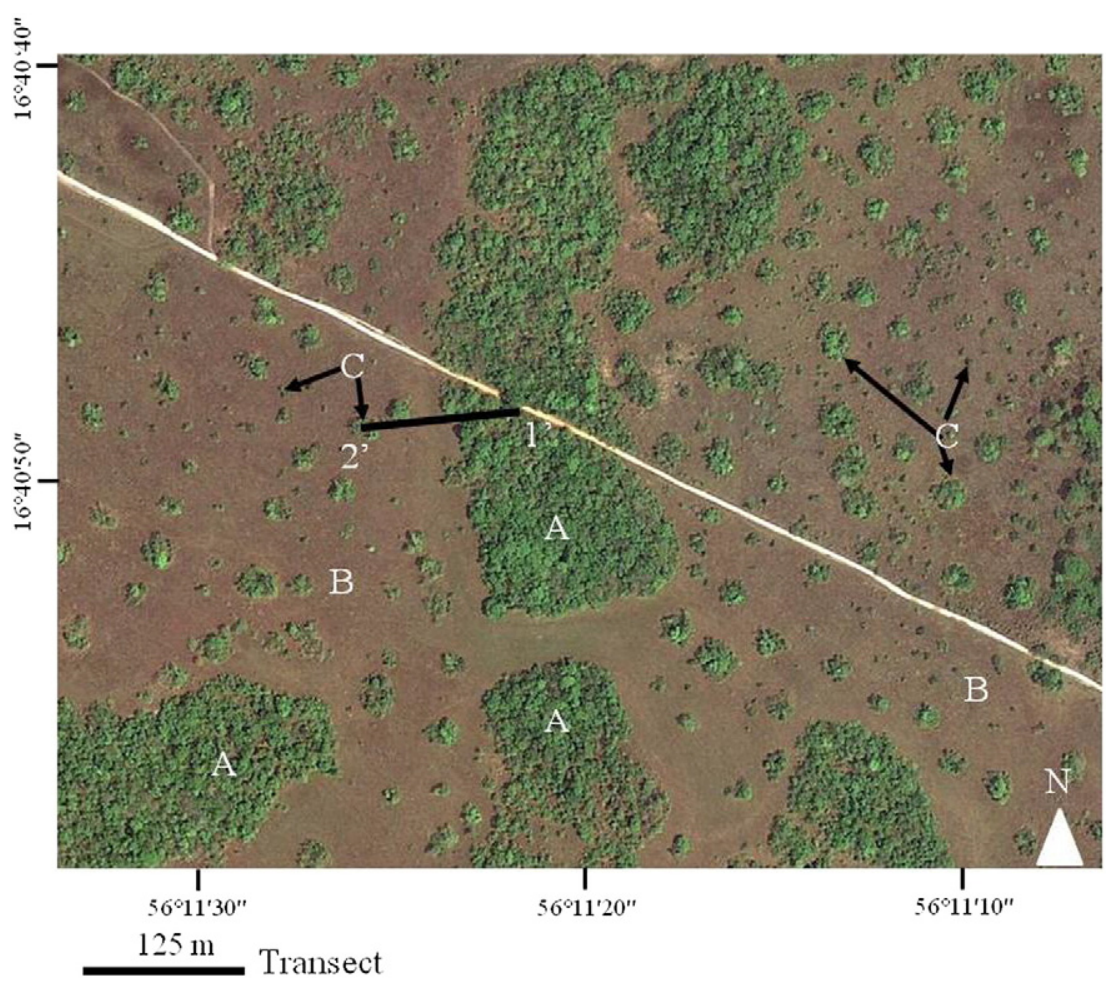

Fig. 2. The studied transect: at the beginning ( $\left.1^{\prime}\right)$, non-flooded paleo-channel (A) with Cerrado vegetation; in the middle, flooded area (B) with grasses; at the end ( $\left.2^{\prime}\right)$, non-flooded mound (C) with semideciduous trees, palms, and bromeliads. Image from Google Earth®.

(Moore and Reynolds, 1989), as well as to calculate the presence of expanding components in the mica structure, according to the formula:

$$
\frac{\mathrm{I}(001) / \mathrm{I}(003)\left(\mathrm{Mg}^{2+}\right)}{\mathrm{I}(001) / \mathrm{I}(003)(\mathrm{EG})}
$$

where I(001) and I(003) are, respectively, the intensity of the $\mathrm{d}_{001}$ and $\mathrm{d}_{003}$ mica peaks on $\mathrm{Mg}^{2+}$ saturated and EG solvated patterns. Values higher than 1 indicate interstratification between mica and an expansive material (Srodón and Eberl, 1984). We also calculated the relative content of iron in the mica structure, using:

$\mathrm{I}(001) / \mathrm{I}(002)$

where $\mathrm{I}(001)$ and $\mathrm{I}(002)$ represent, respectively, the intensity of the $\mathrm{d}_{001}$ and $\mathrm{d}_{002}$ mica peaks on $\mathrm{Mg}^{2+}$ saturated patterns (Huggett et al., 2001). Results higher than 2 indicate a relatively large Fe-content for the octahedral sheet (Brown and Brindley, 1980).

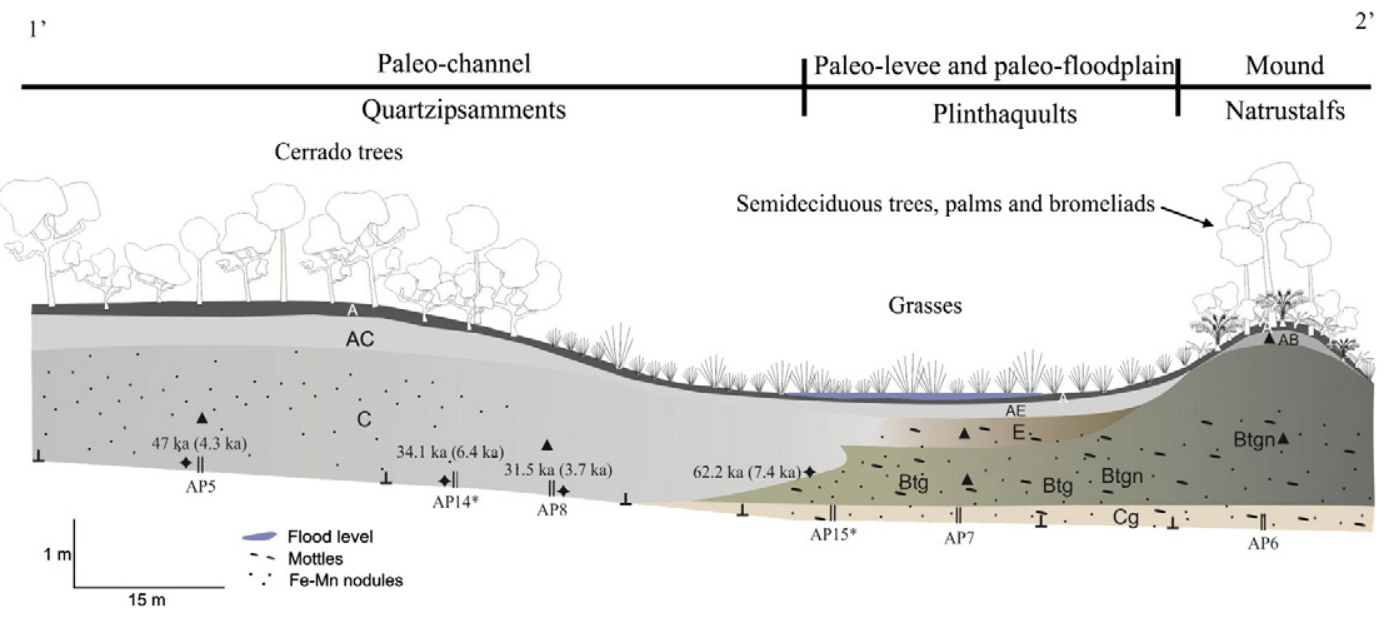

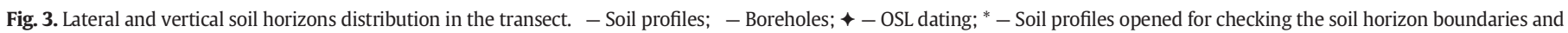
sampling for dating purposes. $\mathbf{\Delta}$ - Horizons sampled for mineralogical analysis. 


\section{Results}

\subsection{General description}

The head of the studied transect $\left(1^{\prime}\right)$ is part of a paleo-channel, a 100 -m-wide landform feature elongated in the north-south direction (Fig. 2). At the end of the transect $\left(2^{\prime}\right)$ is a mound, an isolated and rounded feature with a diameter of $10 \mathrm{~m}$. Both features are not flooded and the present vegetation consists of trees. The features are around $1 \mathrm{~m}$ higher than the lowest part of the transect, which is seasonally flooded (5-10 cm of water) and covered with grasses (Fig. 2).

In the transect it is possible to observe three soil classes (Soil Survey Staff, 2014): Quartzipsamments (AP5, AP14, AP8) occur both on the higher landform feature (paleo-channel), which has Cerrado trees, and in the intermediate/lower part of the transect, with grasses; Phinthaquults (AP7, AP15) occur in the lowest part where grasses are common and; Natrustalfs (AP6) are on the mound with semideciduous trees, palms, and bromeliads at the end of the transect (Fig. 3).

As we can see in Fig. 3, the subsurface sandy horizons (C) are predominant from the higher (AP5) to the lower (between AP8 and AP15) parts of the transect, where there is an abrupt lateral change to horizons that contain more clay (Btg and Cg) (Fig. 3).

The sandy $C$ horizon at the higher part of the transect shows yellowish color, nodules, $\mathrm{pH}_{\mathrm{H}_{2} \mathrm{O}}$ between 5.5 and 6.5 , and low cation exchange capacity (CEC), sum of exchangeable base (S), aluminum saturation ( $\mathrm{m}$ ) and exchangeable sodium saturation (ESP) (Table 1). At the intermediate part of the transect (AP8), the C horizon differs by showing mottling in color, no nodules, and subhorizons with slightly lower
$\mathrm{pH}_{\mathrm{H}_{2} \mathrm{O}}$. However, both show similarities in terms of colors, contents and distribution of sand (Fig. 4), with dominance of sand in similar proportions in all the subhorizons.

The Btg horizon, located at the lowest part of the transect, shows gray matrix color (10YR 6/1) and mottles often with red color (10R 5/ 8). It also shows frequent hard large irregular nodules. Furthermore, this horizon has $\mathrm{pH}_{\mathrm{H}_{2} \mathrm{O}}$ of 4.7 , high CEC, high aluminum saturation (80\%), and low S, which leads to base saturation lower than $20 \%$.

The $\mathrm{Cg}$ horizon, which underlies the Btg, has almost the same attributes of the Btg, including the abrupt lateral change to the $\mathrm{C}$ sandy horizon, but it shows lower aluminum saturation, total clay, and CEC.

Unlike $\mathrm{C}$ and Btg horizons, the lateral changes between horizons nearer the soil surface are indistinct and progressive, for instance between $\mathrm{C}$ and $\mathrm{E}$ horizons. This boundary may be recognized only due to the arising of weakly-cemented nodules, mottles, and yellowish mottling in the $\mathrm{E}$ horizon. Moreover, the $\mathrm{E}$ horizon $\mathrm{pH}_{\mathrm{H}_{2} \mathrm{O}}$ is below 5.3, i.e., it is strongly acid and has a high aluminum saturation, low CEC, and low V. Although the low clay contents and the sand distributions are similar to those of the $\mathrm{C}$ horizon, the $\mathrm{E}$ horizon shows higher silt and slightly lower sand contents (Table 1 and Fig. 4). Close to the mound, the E horizon becomes thinner and the amount of mottles and nodules decreases, showing progressive lateral change to the Btgn horizon.

The progressive lateral change also is observed between Btg and Btgn subsurface horizons, such as verified in horizons nearer the soil surface. A gradual increase in ESP occurs near the mound (Fig. 5): the ESP is $5 \%$ at the flood limit (AT1); $18 \%$ at the intermediate part between the mound and the flooded site (AT3); and almost 40\% at the mound (Fig. 5). Further, horizons with high ESP can be found on the other

Table 1

Selected morphological and chemical properties and particle size of the studied profiles.

\begin{tabular}{|c|c|c|c|c|c|c|c|c|c|c|c|c|c|c|}
\hline \multirow[t]{2}{*}{ Hor } & \multirow{2}{*}{$\frac{\text { Depth }}{\mathrm{cm}}$} & \multicolumn{2}{|l|}{ Color $^{\mathrm{a}}$} & \multirow[t]{2}{*}{$\operatorname{Str}^{\mathrm{c}}$} & \multirow[t]{2}{*}{ Trans $^{\mathrm{d}}$} & Sand & Silt & \multirow[t]{2}{*}{ Clay } & \multirow[t]{2}{*}{$\mathrm{pH}^{\mathrm{e}}$} & \multirow{2}{*}{\multicolumn{2}{|c|}{$\frac{\mathrm{CEC}}{\mathrm{cmol}_{\mathrm{c}} \mathrm{kg}^{-1}}$}} & \multirow{2}{*}{$\frac{\mathrm{V}}{\%}$} & \multirow[t]{2}{*}{$\mathrm{m}$} & \multirow[t]{2}{*}{ ESP } \\
\hline & & Matrix & $\mathrm{M} / \mathrm{Va}^{\mathrm{b}}$ & & & \multicolumn{2}{|c|}{ Total $\left(\mathrm{g} \mathrm{kg}^{-1}\right)$} & & & & & & & \\
\hline \multicolumn{15}{|c|}{ AP5 - Quartzipsamment } \\
\hline A & $0-10$ & 10YR $3 / 3$ & - & G & GR & 885 & 75 & 40 & 5.7 & 2.9 & 1.0 & 34 & 0 & 1 \\
\hline $\mathrm{CA}$ & $10-55$ & 10YR $4 / 4$ & - & SG & GR & 885 & 75 & 40 & 5.3 & 2.2 & 0.6 & 27 & 12 & 1 \\
\hline $\mathrm{Cc} 1$ & $55-80$ & 10YR 5/4 & - & BS & GR & 850 & 100 & 50 & 5.5 & 1.4 & 0.5 & 34 & 0 & 1 \\
\hline $\mathrm{Cc} 2$ & $80-95$ & 10YR 5/4 & - & BS & $\mathrm{CL}$ & 840 & 120 & 40 & 5.6 & 1.4 & 0.6 & 40 & 0 & 2 \\
\hline $2 \mathrm{Cc} 3$ & $95-110$ & 10YR $7 / 4$ & - & SG & $\mathrm{CL}$ & 830 & 120 & 50 & 5.5 & 1.1 & 0.4 & 35 & 0 & 1 \\
\hline $3 C \mathrm{C} 4$ & $110-170$ & 10YR $7 / 3$ & - & SG & $\mathrm{CL}$ & 900 & 75 & 25 & 5.9 & 1.0 & 0.4 & 37 & 0 & 1 \\
\hline $3 \mathrm{Cc} 5$ & $170-200+$ & 10YR $7 / 3$ & - & SG & & 895 & 80 & 25 & 6.5 & 1.8 & 0.5 & 3 & 0 & 0 \\
\hline \multicolumn{15}{|c|}{ AP8 - Quartzipsamment } \\
\hline A & $0-10$ & 10YR 4/2 & - & $\mathrm{G}$ & GR & 880 & 80 & 40 & 5.0 & 2.5 & 0.6 & 23 & 17 & 1 \\
\hline AC & $10-48$ & 10YR $5 / 3$ & 10 YR $7 / 8^{2}$ & SG & GR & 875 & 90 & 35 & 5.5 & 1.4 & 0.3 & 24 & 34 & 1 \\
\hline $\mathrm{C} 1$ & $48-75$ & 10YR $7 / 2$ & $10 \mathrm{YR} 7 / 8^{2}$ & SG & GR & 865 & 110 & 25 & 5.5 & 1.1 & 0.2 & 23 & 0 & 2 \\
\hline $\mathrm{C} 2$ & $75-190+$ & 10YR 7/4 & 10YR $7 / 6^{2}$ & SG & & 885 & 90 & 25 & 5.9 & 0.8 & 0.3 & 33 & 0 & 3 \\
\hline \multicolumn{15}{|c|}{ AP7 - Plinthaquult } \\
\hline A & 0-15 & 10YR 4/2 & & G & GR & 665 & 250 & 85 & 5.4 & 2.7 & 0.5 & 20 & 39 & 1 \\
\hline $\mathrm{AE}$ & $15-32$ & 10YR $6 / 2$ & 10YR $6 / 8^{2}$ & BS & GR & 655 & 270 & 75 & 5.1 & 1.7 & 0.3 & 20 & 46 & 1 \\
\hline E & $32-53$ & 10YR 6/3 & 10 YR $6 / 8^{2}$ & BS & $\mathrm{CL}$ & 605 & 300 & 95 & 5.0 & 1.7 & 0.3 & 17 & 60 & 1 \\
\hline Ec1 & $53-60$ & 10YR $7 / 2$ & 10 YR $6 / 8^{2}$ & BS & $\mathrm{CL}$ & 640 & 320 & 40 & 5.2 & 1.1 & 0.2 & 19 & 45 & 1 \\
\hline Ec2 & $60-72$ & 10YR $7 / 1$ & 10YR $5 / 8^{1}$ & BS & $\mathrm{CL}$ & 610 & 350 & 40 & 5.0 & 1.5 & 0.2 & 17 & 60 & 0 \\
\hline Btgcv & $72-180$ & 10YR 6/1 & $10 \mathrm{R} 5 / 8^{1}$ & BS & $\mathrm{CL}$ & 320 & 330 & 350 & 4.7 & 7.4 & 1.2 & 17 & 80 & 3 \\
\hline $\mathrm{Cgcv}$ & $180-200+$ & 10YR $7 / 1$ & $10 \mathrm{R} 6 / 8^{1}$ & BS & & 640 & 140 & 220 & 5.0 & 4.2 & 1.2 & 3 & 6 & 0 \\
\hline \multicolumn{15}{|c|}{ AP6 - Natrustalf } \\
\hline A & $0-8$ & 10YR $5 / 3$ & - & BS-G & GR & 605 & 280 & 115 & 5.2 & 4.0 & 1.7 & 44 & 4 & 1 \\
\hline $\mathrm{AB}$ & $8-45$ & 10YR 5/3 & - & BS & $\mathrm{CL}$ & 570 & 305 & 125 & 5.4 & 2.8 & 1.1 & 40 & 12 & 1 \\
\hline Btgn1 & $45-120$ & 10YR 4/1 & - & BS & $\mathrm{CL}$ & 465 & 345 & 190 & 6.2 & 3.9 & 3.0 & 76 & 0 & 23 \\
\hline Btgn2 & $120-155$ & 10YR 6/2 & - & BS & GR & 420 & 225 & 355 & 6.2 & 7.7 & 6.6 & 85 & 0 & 37 \\
\hline Btgnc & $155-185+$ & 10YR $7 / 2$ & 10YR $5 / 8^{2}$ & BS & & 365 & 240 & 395 & 6.1 & 7.6 & 5.6 & 74 & 0 & 35 \\
\hline
\end{tabular}

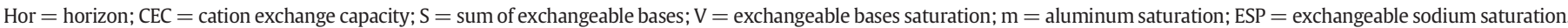

- = absent.

a Moist color.

b $\mathrm{M}=$ mottle color $-{ }^{1}$; Va $=$ variegated color $-{ }^{2}$.

c Structure $-\mathrm{G}=$ granular; $\mathrm{SG}=$ single grain; $\mathrm{BS}=$ blocky subangular.

d Horizon boundaries $-\mathrm{GR}=$ gradual; $\mathrm{CL}=$ clear.

e $\mathrm{pH}$ in water. 
a

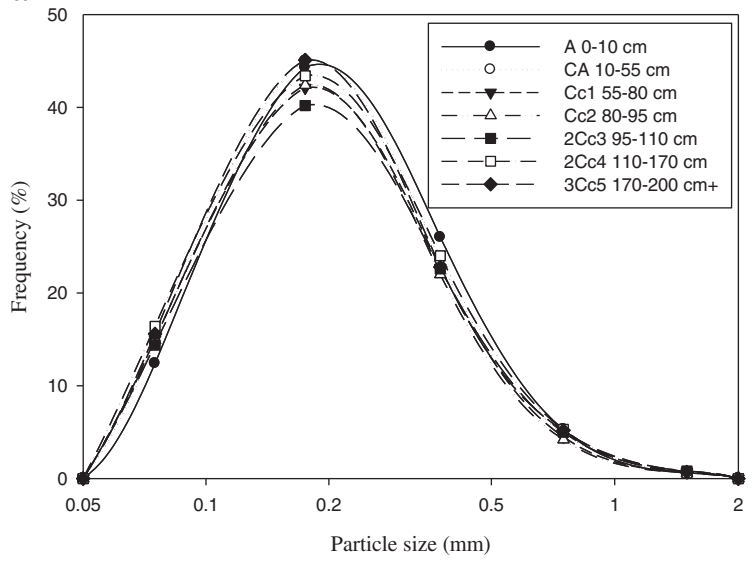

C

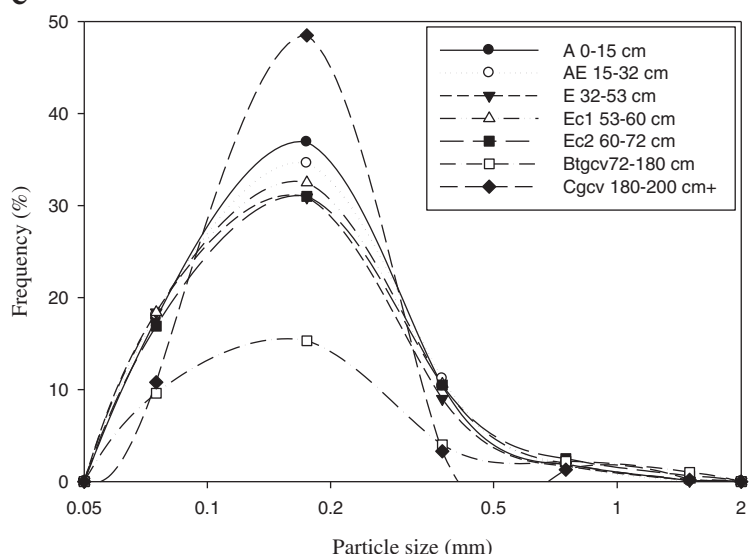

$b$

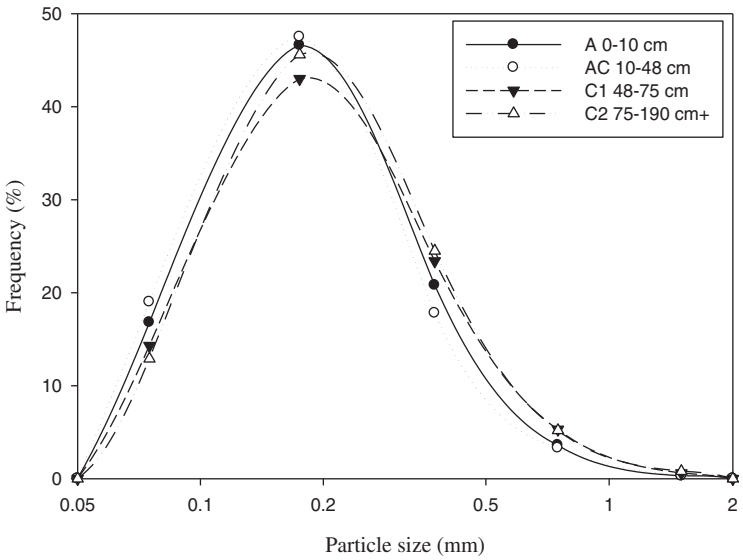

$\mathrm{d}^{50}$

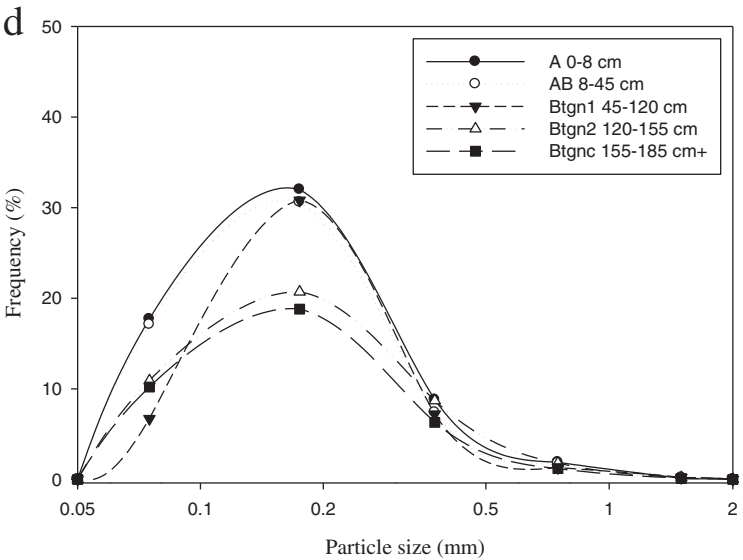

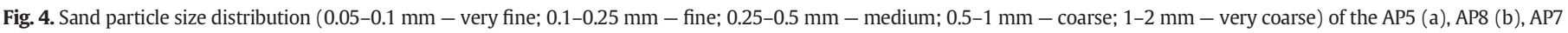
(c) and AP6 (d)

side of the transect, with an ESP of almost 10\% at the flood limit (AT6). Almost all the boreholes, except borehole AT5, show relatively high ESP below the 200-cm depth, in particular borehole AT3, which reaches almost 20\% ESP at the 300-cm depth.
Besides the high ESP, Btgn horizon also has moderately acid $\mathrm{pH}$, high CEC and $\mathrm{S}$, low $\mathrm{m}$ and high $\mathrm{V}$, color between light and dark gray, as well as yellowish brown hue mottling and few nodules at depth. In the Btgn subhorizons described at the mound there are clayey lamellae, grouped

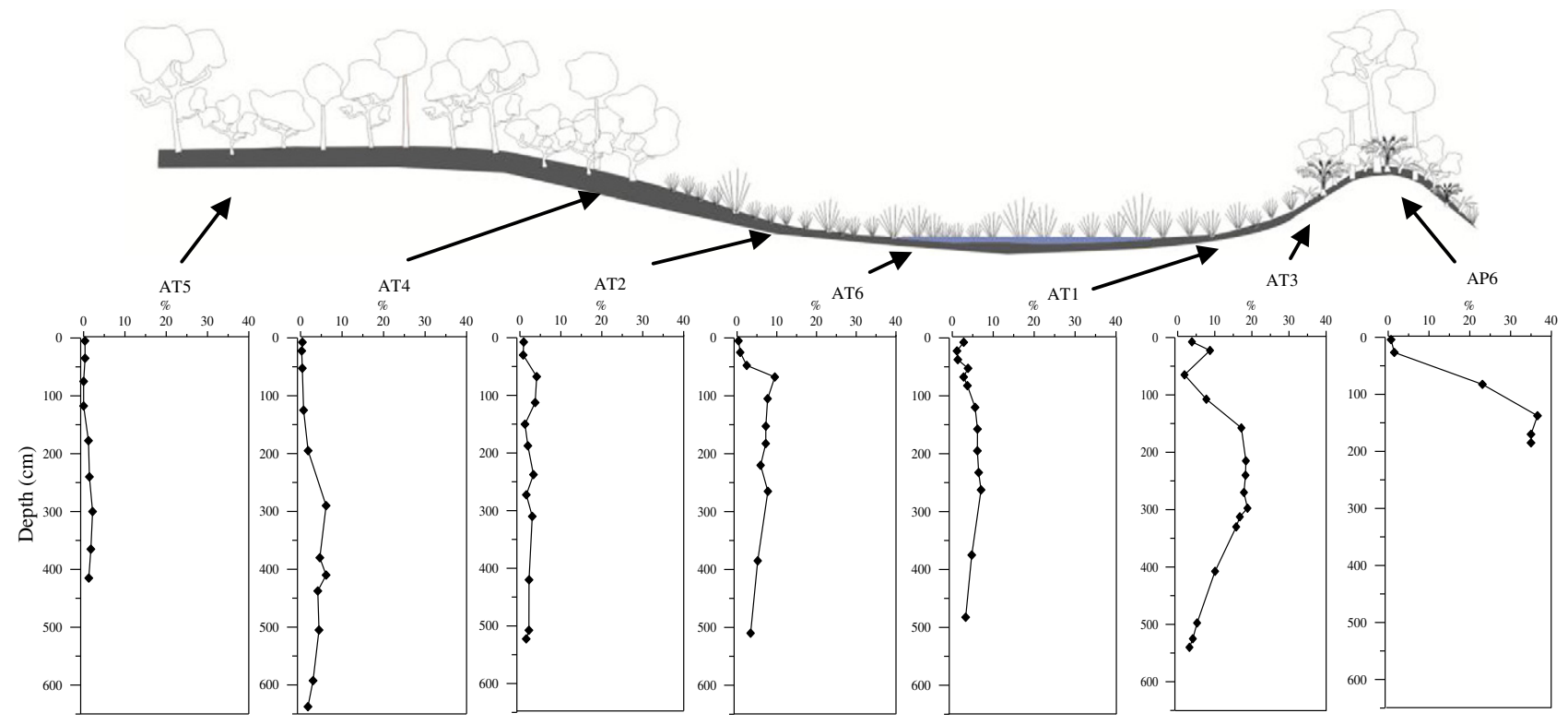

Fig. 5. Exchangeable sodium saturation (ESP) of 6 boreholes and the AP6 profile along the transect. 
and overlapping between $80-90 \mathrm{~cm}$ and $130-140 \mathrm{~cm}$. These lamellae are, on average, between 1 to $2 \mathrm{~cm}$ width, 5 to $10 \mathrm{~cm}$ length and 3 to $5 \mathrm{~cm}$ depth ( $\mathrm{Z}$ axis).

In terms of sand particle size distribution, fine sand (0.1-0.25 mm) was the mode in all the horizons analyzed (Fig. 4). It is noted that the AP5 and AP8 show similarity in terms of quantity and distribution of sand in all the subhorizons. On the other hand, AP7 and AP6, which are at the lower part of the transect and at the mound, respectively, have a different sand particle size distribution than the other profiles. The sand distribution in the Btgcv subhorizon, at the lower part of the transect, is notably similar to that of the Btgn2 and Btgnc at the mound.

\subsection{OSL age dating}

The OSL age dating indicates $47 \mathrm{ka}$ at the $200 \mathrm{~cm}$ depth of the $\mathrm{C}$ horizon in the highest part of the transect (AP5), $35 \mathrm{ka}$ and $31 \mathrm{ka}$ in the intermediate part (AP8 and AP14) and $62 \mathrm{ka}$ in the boundary with the Btg horizon (155 cm depth) (Table 2).

\subsection{Total carbon, total nitrogen and $\delta^{13} \mathrm{C}$}

Below $20 \mathrm{~cm}$, the total carbon content (C) in the profile at the paleochannel (AP5 and AP8), and at the flooded part of the transect (AP7), was similar. However, the AP7 surface horizon has $0.1 \%$ more carbon content than the AP5 and AP8 surface horizons (Fig. 6a). The mound profile (AP6), had the highest total C content among the profiles studied in the transect, reaching double that of other profiles. Total $\mathrm{N}$ content was also higher in the mound profile, and similar among the other profiles, mainly in horizons near the soil surface (Fig. 6b).

Carbon isotopic fractionation of the AP5 profile showed a $-23 \%$ signal at $100 \mathrm{~cm}$ depth, slight enrichment until $70 \mathrm{~cm}$ and, from this depth up to the soil surface, an impoverishment of the signal, reaching $-25 \%$, which indicates that the carbon comes mainly from the $\mathrm{C} 3$ plants (Fig. 6c).

AP8 profile had an isotopic signal between -21 and $-19 \%$, which indicates the contribution of $\mathrm{C} 3$ and $\mathrm{C} 4$ plants. These results can be explained due to current soil profile position in the landscape, exactly at the boundary between Cerrado trees (C3) and grasses (C4).

In deeper horizons of AP6 and AP7 profiles (around $180 \mathrm{~cm}$ depth), the $C$ isotopic signal was $-20 \%$, indicating a mix of C3 and C4 plants. Nevertheless, from this depth up to the soil surface, AP6 profile shows an increasing impoverishment in its isotopic signal, reaching $-27 \%$ at the surface horizon, which indicates progressive contribution of C3 plants. On the other hand, AP7 profile shows an increasing enrichment in isotopic signal, reaching $-16 \%$ at the surface, i.e., progressive contribution of C4 plants (Fig. 6).

\subsection{Mineralogy}

The total clay fraction is dominated by kaolinite, with lesser amounts of mica and smectite (Table 3). The mineralogical assemblage is the same regardless of the position on the transect. Despite the variable

Table 2

Analyzed OSL samples from the studied transect and their burial doses, dose rates, and calculated date (age).

\begin{tabular}{|c|c|c|c|c|}
\hline \multirow[t]{2}{*}{ Lab code } & \multirow[t]{2}{*}{ Sample ID } & Burial dose & Dose rate & Age \\
\hline & & (Gy) & $\left(\right.$ Gy year $\left.{ }^{-1}\right)$ & (ka) \\
\hline 2929 & AP5 $-200 \mathrm{~cm}$ & $31.0 \pm 1.4$ & $660 \pm 30$ & $47.0 \pm 4.3$ \\
\hline 3388 & AP14 - $200 \mathrm{~cm}$ & $14.6 \pm 0.4$ & $416 \pm 57$ & $34.1 \pm 6.4$ \\
\hline 2931 & AP8 $-190 \mathrm{~cm}$ & $17.5 \pm 0.8$ & $560 \pm 40$ & $31.5 \pm 3.7$ \\
\hline 3390 & AP15 $-155 \mathrm{~cm}$ & $38.0 \pm 2.6$ & $611 \pm 42$ & $62.2 \pm 7.4$ \\
\hline
\end{tabular}

amount of each mineral depending on the pedon position, the differences among them are small. Therefore it is hard to say whether these differences are related to soil processes triggered by their position in the transect or to the XRD semi-quantitative method used for this purpose.

Present in small amounts, the mica has calculated indexes that indicate its interstratification with smectite in the Btgn, Btg, part of the $\mathrm{C}$ horizon, and in the $A B$ horizon at the mound (Table 3 ). Another index, which represents the Fe-content in the octahedral sheet, shows mica with low Fe-content and no relationship with the transect location (Table 3). In total silt and sand, quartz dominates, with traces of mica and anatase (data not shown).

\subsection{Soil micromorphology}

Photomicrographs from the Btg horizon at the flooded part of the transect show well sorted sand, a brown micromass, minimal porosity and typic-aggregate ferruginous nodules, weakly to moderately impregnated (Fig. 7a). The sparse porosity in this horizon may be related to the dense and complete infilling of voids by fine materials (Fig. 7b). Clay coatings with microlamination and sharp extinction bands occur within ferruginous nodules, indicating a possible fossilization of this pedofeature by the process of nodule formation (Fig. 7c and d).

The Btgn horizon at the mound shows well sorted sand grains, a micromass that is mainly dark brown, cavity porosity (rounded to sub-rounded smooth voids), and few typic ferruginous nodules. This horizon has two kinds of fine material pedofeatures: the first one is limpid and a yellowish-brown color, and the second one is opaque and a dark-brown color (Fig. 8). The translucent fine material can be seen as a coating on void walls or as dense and incomplete infilling of voids, both showing anisotropy (Fig. 8a, c, and d). On the other hand, the opaque fine material occurs as fine lines, elongated and inset between sand-size material, and is isotropic (Fig. 8b and $\mathrm{g}$ ). The isotropy of the material is seen in more detail in Fig. 8e and $\mathrm{f}$.

The isotropic pedofeatures of fine material from two samples taken from the frontal (Fig. 8g) and lateral (Fig. 8h) walls of the profile show arrangement peculiarities. In the frontal sample, the positive slope line of fine material is inset between a porphyric c/f-related distribution, which merges to other two lines of fine material, a thinner one above and a coarse one below (Fig. 8g). The lateral sample of this feature shows the same related distribution, however, small layers of fine material with negative slope are observed in the fabric, which are tangent to each other (Fig. 8h).

Although a porphyric c/f-related distribution predominates in the Btgn horizon, two different zones can be clearly separated in Fig. 8a: the first has a dense groundmass with a porphyric c/f-related distribution and; the second has higher porosity, with an enaulic c/f-related distribution pattern and some clay coatings.

The observed lamellae in the Btgn horizon (at AP6 pedon) show anisotropic fine material stratified in different colors, varying among brown and greenish-brown in plane-polarized light (PPL). These features are slightly concave, microlaminated, and weakly oriented (Fig. 9). In this case, when a long void is filled with illuvial fine materials, it may show a weak orientation, resulting in wide extinction bands in cross-polarized light (XPL) (Kühn et al., 2006), as shown in Fig. 9.

The voids above these lamellae were filled with fine material of similar color to that of the lamellae stratification. It is important to highlight that, as noticed in the soil macromorphology, these lamellae are not laterally continuous, being a few centimeters in width (y axis), length ( $x$ axis) and depth (z axis).

The $C$ horizons of the AP5 and AP8 pedons were sampled for soil micromorphology analyses. However, even though great care was taken during sampling and transportation, the samples of this highly friable horizon were disrupted and broken, so it was not possible to prepare thin sections. 

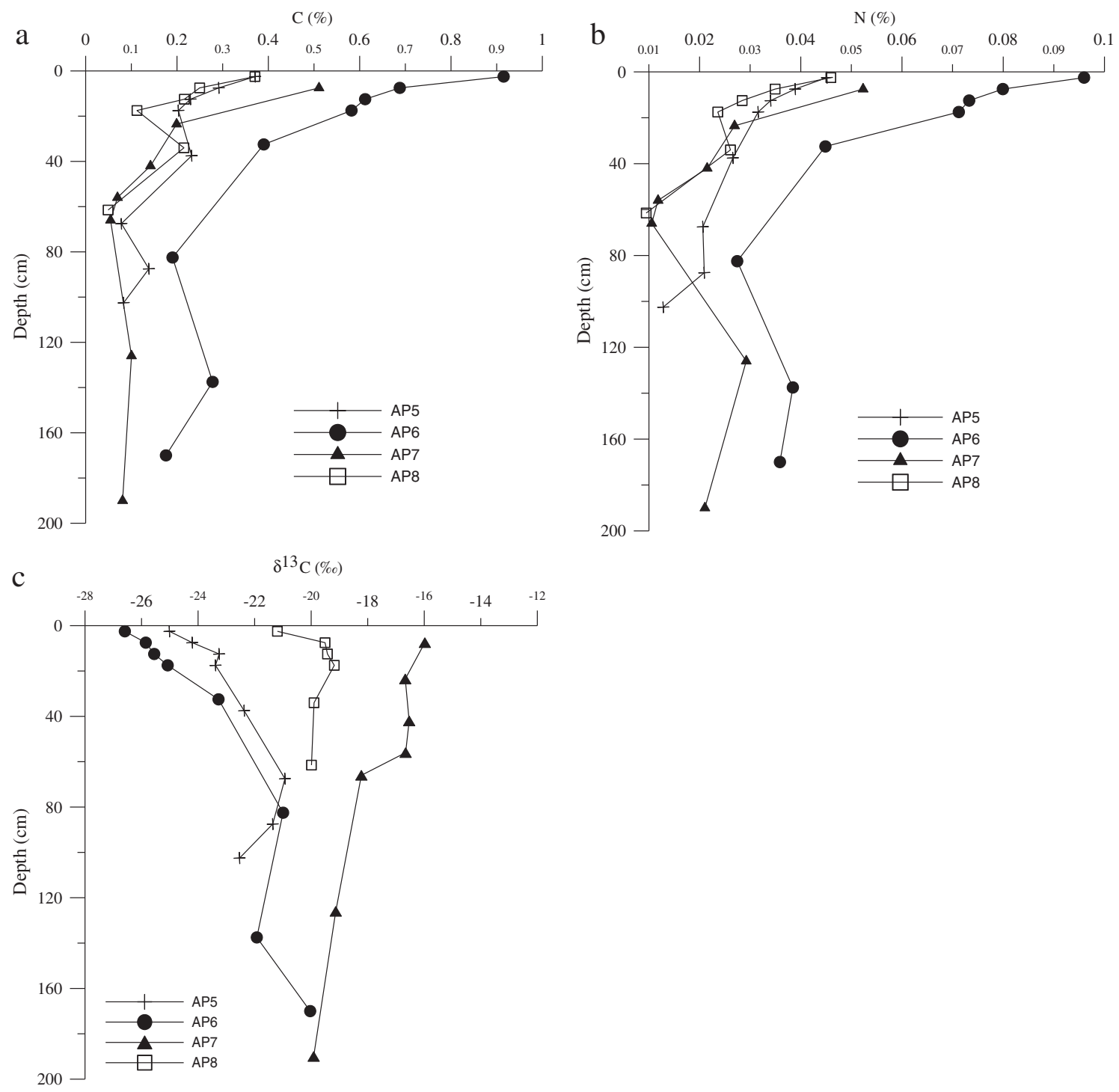

Fig. 6. Total carbon (a), nitrogen (b) and $\delta^{13} \mathrm{C}(\%)$ (c) in the profiles AP5, AP6, AP7, and AP8.

\section{Discussion}

\subsection{Origin of sediments}

The geomorphic evidence observed in satellite images and in loco, together with the OSL datings, soil morphology, and lateral distribution of the horizons confirm that the transect landscape is part of a Pleistocene fluvial system (Farrell, 2001; Nichols, 2009; Nichols and Fisher, 2007). The low slope gradients of the landforms and their sedimentary architecture, which has abrupt boundaries between fine and coarse sediments, are typical of this type of fluvial sedimentary environment at the limit between channel and levee deposits (Farrell, 2001; Nichols and Fisher, 2007).

Thus, the sedimentary architecture, as described above, and the regional and local geomorphic context, with long landform features (paleo-channels) and lobes, indicate that the sediments of the transect are associated with the activity of the São Lourenço fluvial fan (Assine et al., 2014; Corradini and Assine, 2012; Nascimento, 2012). Although Corradini and Assine (2012) have indicated Holocene age for the sedimentary lobe of the transect, dating analyses revealed an Upper Pleistocene age to the depositional system responsible for sedimentation in this area. A channel belt comprising multiple channels or in-channel

Table 3

Semi-quantitative mineral proportions and indexes of mica in the total clay fraction.

\begin{tabular}{|c|c|c|c|c|c|c|}
\hline Mineral & AP5 Hor. C & AP8 Hor. C & AP7 Hor. E & AP7 Hor. Btg & AP6 Hor. AB & AP6 Hor. Btgn \\
\hline \multicolumn{7}{|l|}{ Proportions (\%) } \\
\hline Kaolinite & 78 & 74 & 79 & 82 & 78 & 79 \\
\hline Mica & 12 & 14 & 15 & 12 & 17 & 11 \\
\hline Smectite & 10 & 12 & 6 & 6 & 5 & 10 \\
\hline \multicolumn{7}{|l|}{ Mica Indexes } \\
\hline $\mathrm{I}(001) /(003)\left(\mathrm{Mg}^{2+}\right)(001) /(003)(\mathrm{EG})$ & 1.4 & 0.4 & 1.0 & 2.2 & 2.6 & 2.1 \\
\hline $\mathrm{I}(001) /(002)\left(\mathrm{Mg}^{2+}\right)$ & 0.8 & 1.3 & 0.7 & 0.7 & 1.1 & 1.0 \\
\hline
\end{tabular}



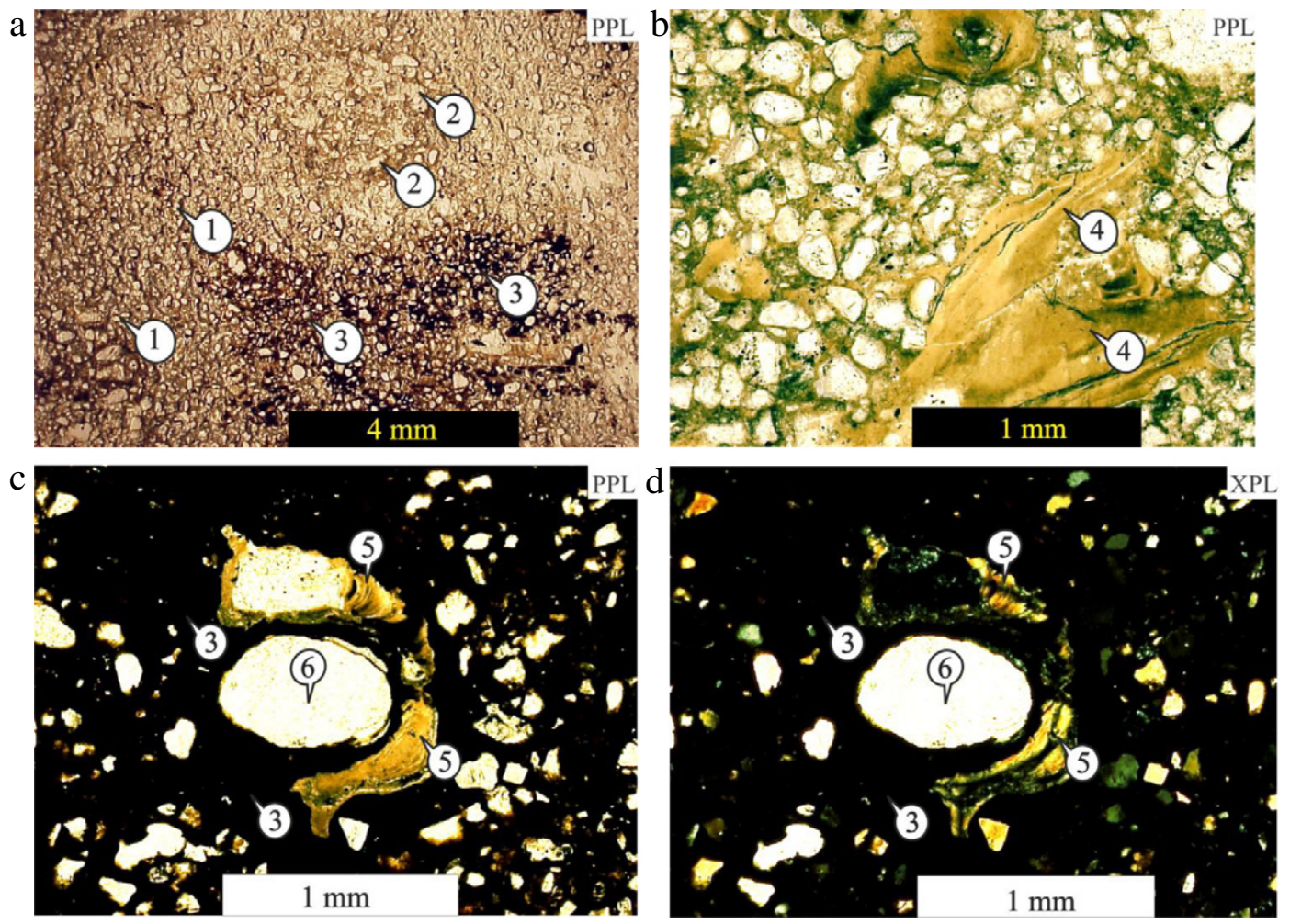

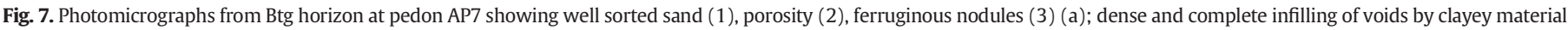
(4) (b); and clay coating (5) and a central quartz grain (6) within ferruginous nodules, suggesting a possible fossilization of the pedofeature (c and d).

bars seems to have been active during this age, since the dating results indicated different ages within a short distance (Nichols, 2009).

Silt and sand mineralogy of horizons from the transect, dominantly with quartz and traces of mica and anatase, are associated with Mesozoic and Paleozoic sedimentary rocks, rich in quartz, which occur at the catchment area of the São Lourenço fluvial fan (Barros et al., 1982).

\subsection{Genesis and evolution of the transect}

As described above, sandy horizons and sediments predominate from the higher part of the transect to the lower part, where there is an abrupt transition between sandy and clayey horizons and sediments (Fig. 3). This seems inconsistent for depositional systems dominated by a fluvial fan, because in these environments channel-levee deposits usually occur at the higher position in this fluvial landscape, where there is the transition from the coarser sediments to the finer (Mackey and Bridge, 1995; Slingerland and Smith, 1998).

C isotope fractionation suggests that the part of the landscape that is currently flooded previously had a vegetation cover composed of both grasses and trees, which gradually came to have a predominance of grasses. At the mound, the mix of the two kinds of plants was progressively replaced by trees (Farquhar et al., 1989). Apparently, the lower part of the transect and the mound were once covered by C3 and C4 plants.

Thus, the transition between sandy and clayey horizons at the lower part of the transect, inconsistent for fluvial fan systems, together with the $C$ isotope fractionation, suggests that a gradual and sluggish erosional degradation of the fluvial landforms was responsible for shaping the landscape. This likely occurred due to the successive cycles of flooding since the Upper Pleistocene, which contributed to the loss of primary porosity (tight packing) of the sediments and to their remobilization to the other part of the system (Nichols, 2009). Considering that the degradation began at the boundary of the higher landform features, where the flooding has more action (Girard et al., 2010), the inner higher landform was then preserved. Since the Upper Pleistocene, when the initial system was configured, this transect had likely been eroded and submitted to flooding and water saturation, which led to the change from C3 to C4 plants, mainly grasses.

At the mound, on the other hand, the reverse process occurred, with gradual changes to plants not adapted to flooding. Besides the gradual contribution of $\mathrm{C} 3$ plants, the $\mathrm{C}$ and $\mathrm{N}$ contents are higher when compared with other pedons from the transect, as are $\mathrm{CEC}, \mathrm{V}, \mathrm{pH}$ and average clay content. These results, added to the occurrence of clayey lamellae without lateral continuity in the field and isotropic fine material elongated in photomicrographs of the Btgn, may be indicative of the termite activities on the formation of this landform (Black and Okwakol, 1997; Lal, 1988; Lee and Wood, 1971; Miedema et al., 1994; Mujinya et al., 2013; Sarcinelli et al., 2009).

Although the higher $\mathrm{C}$ and $\mathrm{N}$ contents may be related to the higher average clay content at the mound, which contributes to soil organic matter stabilization (Zinn et al., 2005), the influence of the termites cannot be excluded. At the lower part of the transect, flooded and covered by grasses, even with lower clay content in superficial horizons, higher $\mathrm{C}$ contents would be expected than at the mound, which is covered by trees (Carvalho et al., 2010; Guo and Gifford, 2002), inasmuch as the grasses, that produce significant quantities of biomass, and the flooding, up to six months in duration, favors the accumulation of soil organic matter (Buol et al., 2011; Van Breemen and Buurman, 2002). Thus, the higher $\mathrm{C}$ and $\mathrm{N}$ contents at the mound may be associated with termites, because these insects select and mix organic and mineral particles during the construction of their nests (Jouquet et al., 2002). Also, after eating these particles (geophagy), their digestive system changes the 

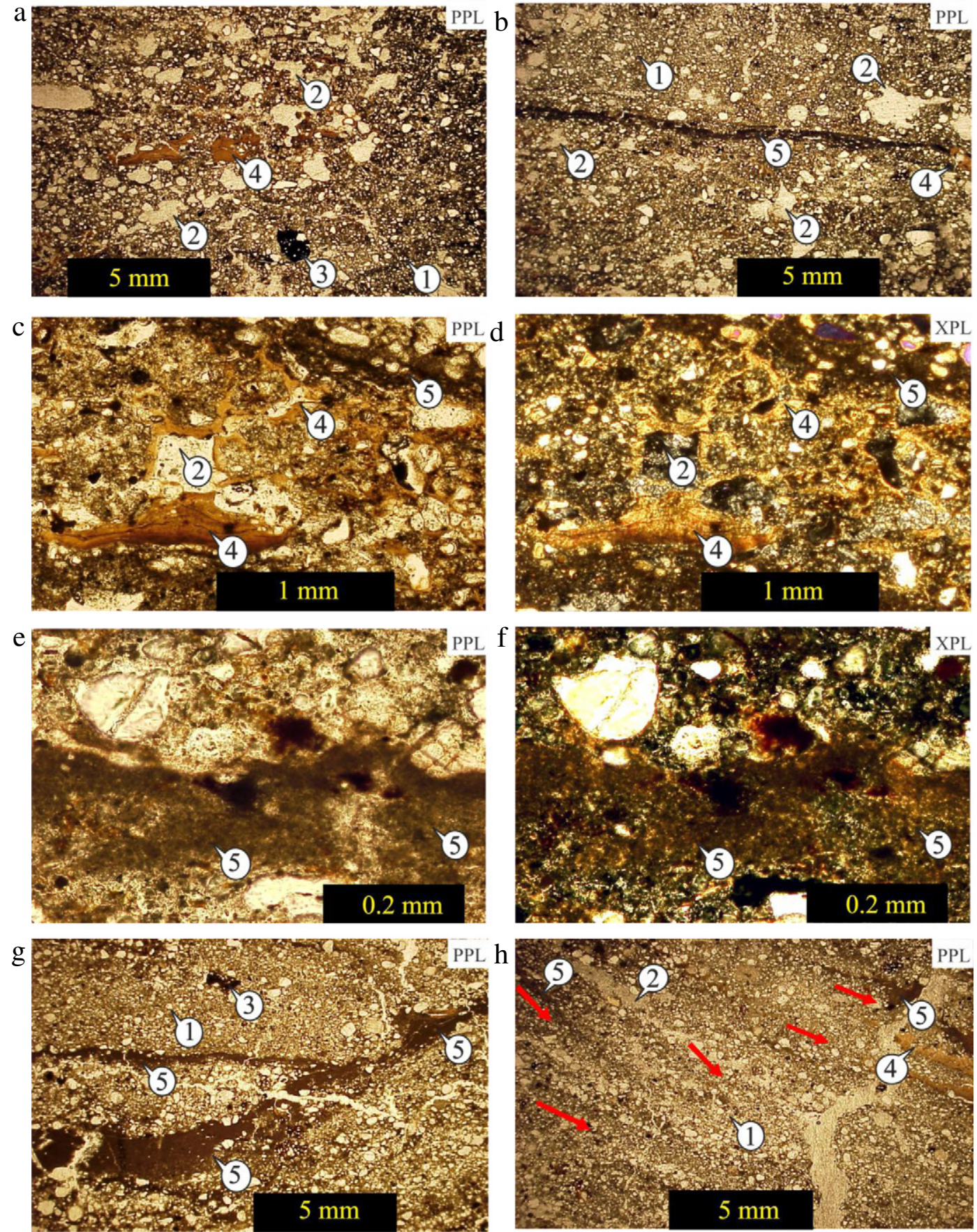

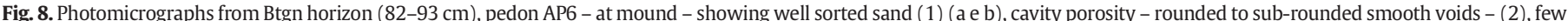

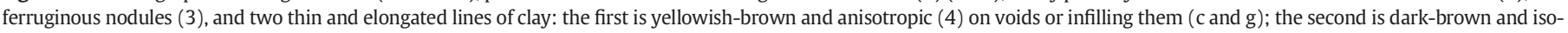

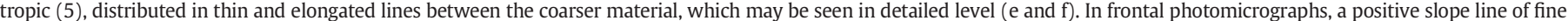

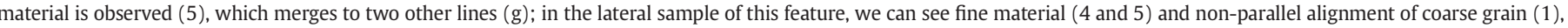
which intersection between each other ( $\mathrm{h}-$ red arrows indicate the alignment).

organic matter by physical and chemical processes, leading to increased humification and the formation of organic-mineral complexes that protect the organic matter against the mineralization (Brauman, 2000).

The higher average clay content at the mound may also be assigned to termites, because they select finer particle sizes during the construction of nests (Abe et al., 2012; Jouquet et al., 2002). The presence of fine mineral particles, coupled with the SOM, increases the CEC (Lal, 1988; Mujinya et al., 2013; Sarcinelli et al., 2009). Though the high pH at the mound may be related to the higher ESP, the influence of the termites cannot be excluded, because these organisms have a high $\mathrm{pH}$ in their gut (Brune and Kühl, 1996).

Both the kinds and amounts of clay minerals at the mound are virtually unchanged compared to other parts of the transect, except for the interstratification index, which is higher at the mound. While termites cause a number of changes in the soils, their saliva and the associated fungus decrease the mica crystallinity, but do not affect the interstratification of this mineral with smectite (Jouquet et al., 2002, 2007). Similarly, other researchers working with termite activity suggest that kaolinite 

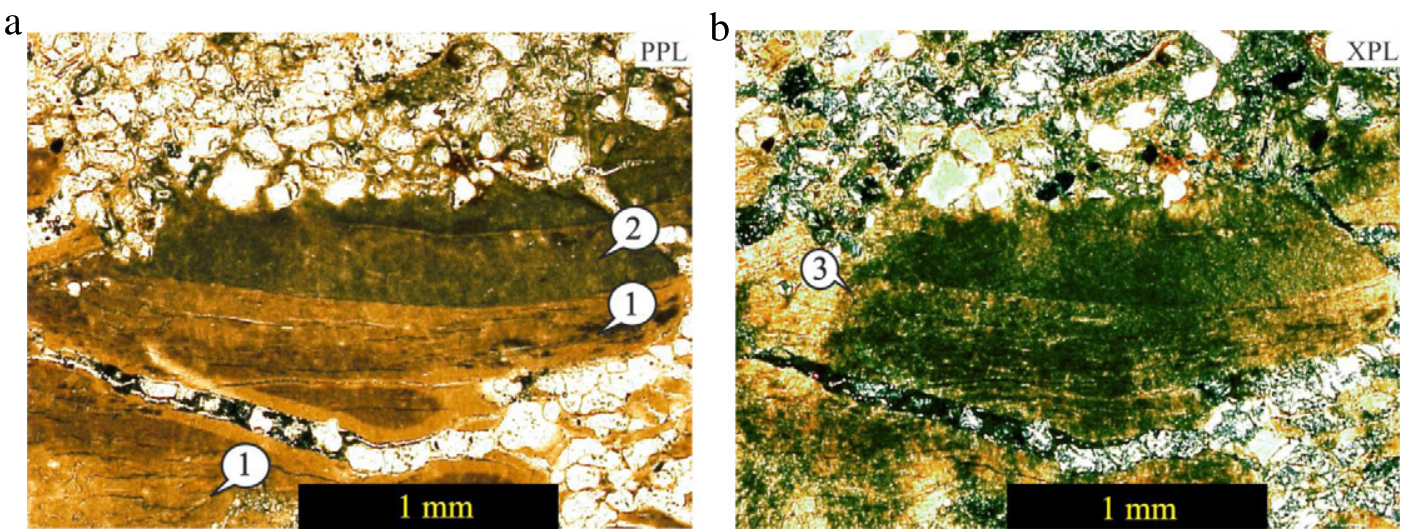

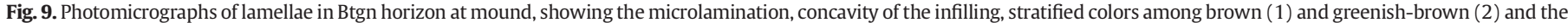

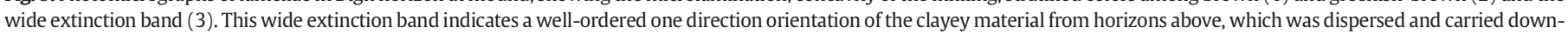
ward infilling voids opened by termites.

loses crystallinity after passing through the gut of these insects, due to its high pH (Brune and Kühl, 1996; Schaefer, 2001).

The presence of two areas with different related distribution in the Btgn photomicrographs may be an indication of biological activity. While termites may decrease soil macroporosity in specific spots by admixing saliva with organic and mineral matter (Lal, 1988), current research indicates that, overall, soils with termite activity are more macroporous (Léonard and Rajot, 2001). This suggests that the sideby-side enaulic and porphyric related distribution in the same photomicrograph is related to this biological activity (Mermut et al., 1984).

The isotropic fine material that has clay, silt, and organic matter as components, arranged in straight lines in Btgn, may be attributed to

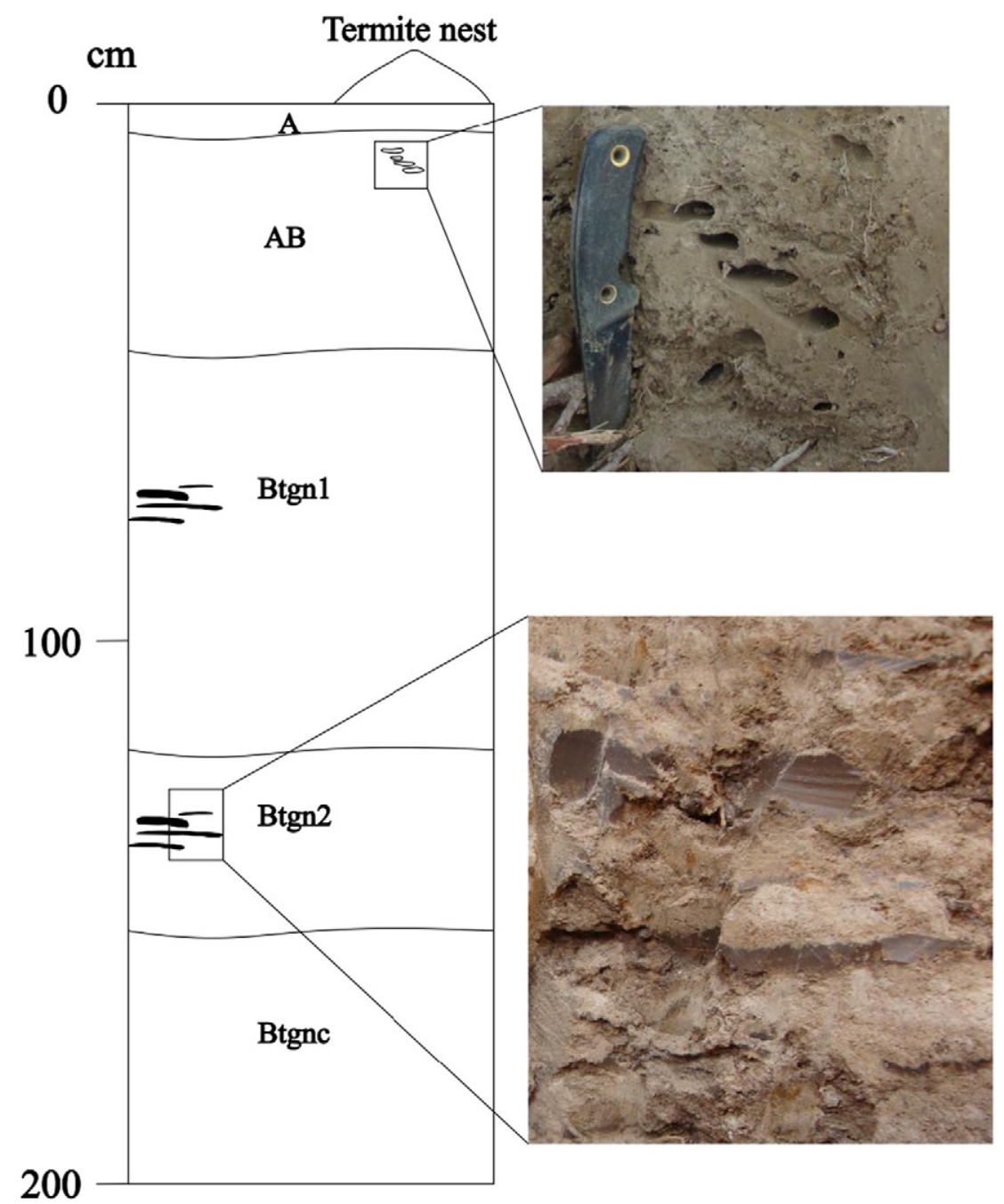

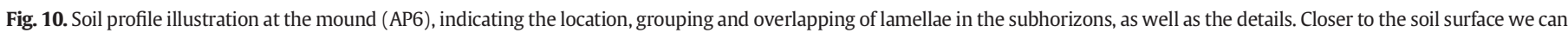
see the channels opened by current termite activity. 
sedimentation processes (Kemp, 1999; Kemp et al., 2004, 2006), to the walls of channels built by termites, which use fine materials for wall stabilization (Cosarinsky, 2011; Kooistra and Pulleman, 2010; Mermut et al., 1984), or to old soil surfaces that suffered sealing or crusting (Kemp, 1999; Mason et al., 2007). While an isotropic pattern may be an indicative of sedimentation in a depositional system (Kemp et al., 2004, 2006), in fluvial sediments the presence of straight lines connected by oblique angles, such as observed in this study (Fig. 8g), seem unlikely (Kemp, 1999; Van der Meer and Menzies, 2011). On the other hand, the mechanism used by the termites to stabilize the channel walls (Cosarinsky, 2011; Kooistra and Pulleman, 2010; Mermut et al., 1984), as well as the crusting or sealing of old soil surfaces (Kemp, 1999; Mason et al., 2007), could generate features as observed in this work.

The anisotropic fine material that occurs in the lamellae, which has a mild concavity, color stratification and wide extinction band, may be associated with ancient soil surfaces or with infilling of cavities opened by termite activity (Miedema et al., 1994). As described above, both the mound and the currently flooded part of the transect apparently were once part of the same non-flooded surface. We can hypothesize that the locations with lamellae were small shallow holes filled with fine materials transported a short distance by low energy surface water movements. Subsequently termite activity added material to the soil surface, burying the surface containing the small holes filled with fine material. However, this hypothesis seems unlikely because the lamellae macromorphology, grouped and overlapping (Miedema et al., 1994), as described in the results, is too complex to be formed only by this process (Fig. 10).

The occurrence of lamellae in specific locations, with a complex morphology (Fig. 10) and color stratification of weakly oriented anisotropic material (Fig. 9), suggests the process of clay illuviation from overlying horizons to cavities constructed by termites (Miedema et al., 1994). If these features were formed by sedimentary processes, besides isotropy, the fine material would not show color stratification and a wide extinction band (Van der Meer and Menzies, 2011). In this case, the absence of a sharp extinction zone does not exclude clay illuviation as forming this fine material, because this process also generates weak clay orientation and a wide extinction band when filling large voids (Kühn et al., 2006). In this feature, clays from upper horizons were dispersed due to the high level of sodium and then were mobilized by movement of water downward within the solum, moving clay through pores to the large cavities constructed by biological activity, where it was deposited as dense complete infillings (Fig. 9). Miedema et al. (1994) and Mujinya et al. (2013), working on termite mounds, observed similar macroand microfeatures: large voids with a dense complete infilling composed of fine material stratified with different colors and with microlamination. For comparison, we can see current termite cavities in the topsoil of the AP6, which show grouping and overlapping of lamellae similar to that observed in subsurface horizons (Fig. 10) (Miedema et al., 1994).

All these data, macro- and micromorphology of soils, $\mathrm{C}$ isotope fractionation, $\mathrm{C}$ and $\mathrm{N}$ contents, chemical attributes, and geomorphic data suggest that the mound is a result of successive cycles of erosion of termite nests (Ellery et al., 1998; McCarthy et al., 1998; Oliveira-Filho, 1992). According to Lee and Wood (1971), the erosion laterally redistributes the termite materials, thereby forming $0.0125-0.1 \mathrm{~mm}$ of soil per year. Thus, the isotropic fine materials observed by this study may be remnants of ancient surfaces of the mound that experienced sealing or crusting (Kemp, 1999), from which under- and over-lapping materials were eroded from the termite nests. This must reflect the environmental conditions during the landform formation, with a less abundant vegetation during the Holocene (Zech et al., 2009), that allowed more erosion from raindrop impact on the soil surface.

The gradual decrease of the $C$ isotope signal from below to the mound topsoil indicates that the construction of termite nests constantly added materials to the surface and those were redistributed nearby by erosion and weathering (Black and Okwakol, 1997). This termite activity kept the mound elevated and mostly isolated from flooding that is common in the Pantanal, thereby preventing the degradation of this landform and leading to the progressive habilitation and predominance of C3 plants, which do not tolerate flooding.

Within a single lobe, mounds are regularly distributed, following paleo-channel alignments, which suggests that mounds are remnants of an original surface (Nascimento, 2012); yet at the studied mound considerable evidence of termite activity was observed. The question that still remains, in this case, is whether the mound was the result of the differential erosive processes and was subsequently inhabited by termites (Silva et al., 2010) or whether these insects were a key influence on mound formation, constantly bringing material to soil surface and preventing it from eroding (Ellery et al., 1998; McCarthy et al., 1998; Oliveira-Filho, 1992).

Based on geomorphologic knowledge of fluvial fans, as well as the whole physical, chemical, mineralogical, dating, $C$ isotopic fractionation, morphological, and micromorphological data from the soils, it is possible to establish a simple model of evolution of the transect (Fig. 11).

The activity of the São Lourenço fluvial fan during the Upper Pleistocene was responsible for the sedimentary architecture with channel deposits, which occurs at the high part of the transect, and levee and floodplain deposits, which occur from the high (levee) to the low part (floodplain) of the transect (Fig. 11a). Trees and grasses, common in the whole transect, changed progressively to grasses at the low part due to the seasonal flooding, which also contributed to starting the termite activity and erosion and lowering of the highest landform features (Fig. 11b). Flooding and soil water saturation cycles certainly contributed to loss of initial porosity of the sediments and to their local remobilization, even in small amounts, to other low sites of the system. The destruction of successively abandoned termite nests added materials to surface, making this part progressively higher, less subject to erosion, and non-flooded, which led in a gradual change to C3 plants (Fig. 11c). The higher parts of the transect with channel and levee sediments, were partly eroded, leaving the boundary between the channel and levee in the lower part of this transect (Fig. 11d).

It seems unlikely that the great variation of the $\mathrm{C}$ isotopic fractionation in short distance is related to vegetation changes due to previous climatic oscillation. If this were the case, all soil profiles would show isotopic signals indicating those effects. Thus, the isotopic signal changes within the short distance are related to the changes in flooding dynamics in response to evolution of the transect. Therefore, even if climate variations occurred since the initial configuration of the sediments (Kuerten et al., 2013; McGlue et al., 2012; Zech et al., 2009), apparently they were not extreme enough to change the vegetation.

\subsection{Soil-forming processes}

The current evidence of pedogenic processes reflects the effects of environmental conditions on soil genesis since sediments were deposited during the Pleistocene. Although the hierarchy of the processes has not been fully established by the results of this study, it is possible to develop some hypotheses of soil evolution along the transect.

Clay illuviation seems to have occurred in the original fine sediments of the transect, as soon as the soils were not saturated with water. Strong evidence of this are the clay coatings that have microlamination and extinction zones preserved within ferruginous nodules in the Btg (seasonally flooded part of the transect), suggesting that clay illuviation preceded the seasonally flooded environment that led to the Fe segregation and nodule formation (Plinthization) (Van Breemen and Buurman, 2002). Clay illuviation likely took place even under the seasonal flooding environment, inasmuch as voids completely filled with gray materials can be observed (Gleization).

Evidence of clay illuviation was also observed at the mound, where clay coatings, in their strongest expression, fill voids, contributing to the $\mathrm{Bt}$ formation. However, because it is a sedimentary environment 

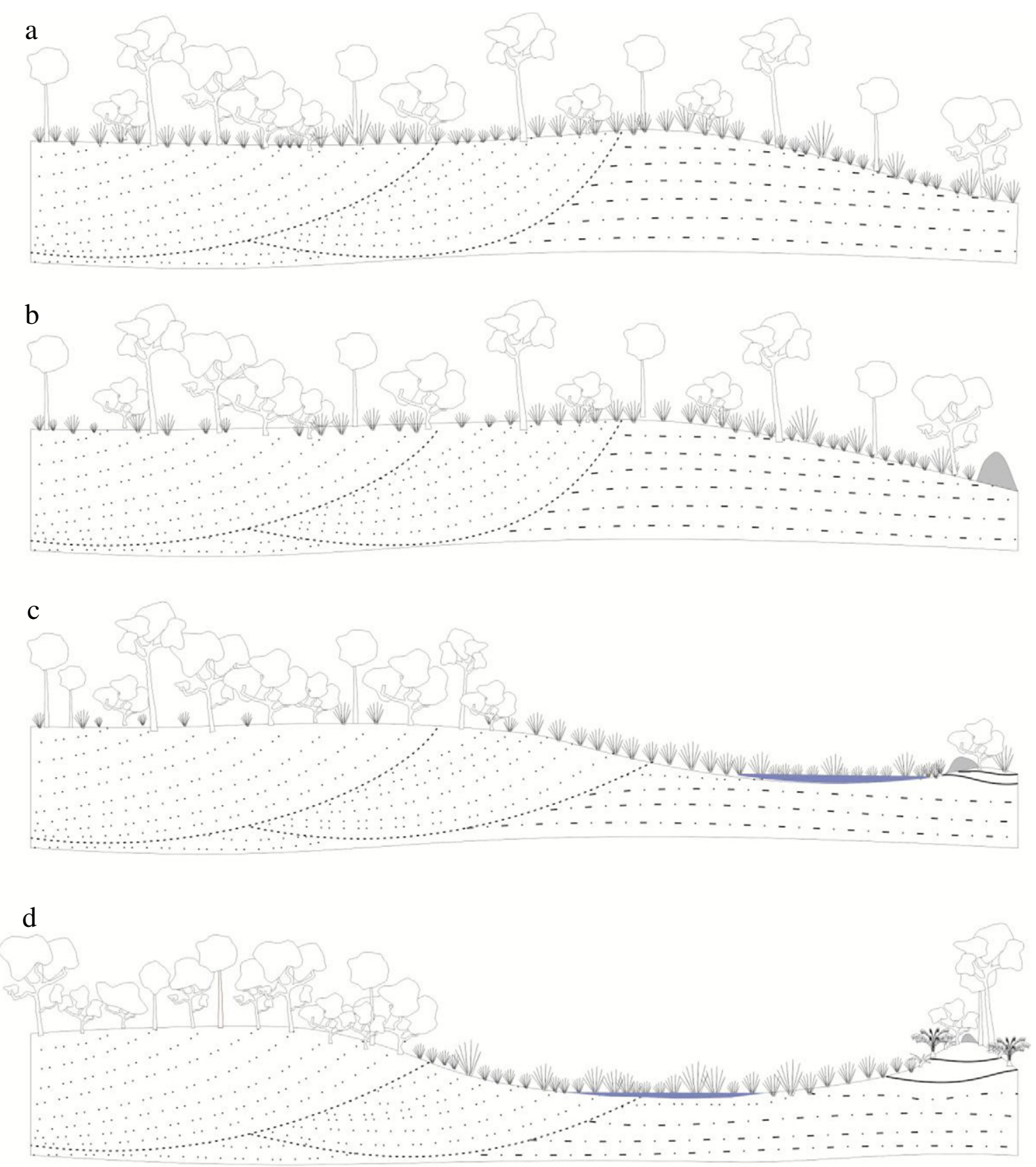

…..... Channel sediments $\quad::-: \quad$ Levee and floodplain sediments

\section{= Materials from the nest erosion}

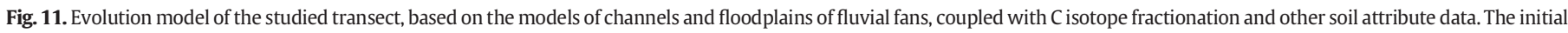

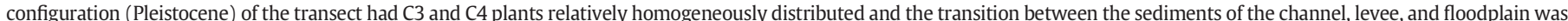

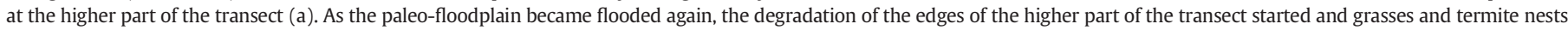

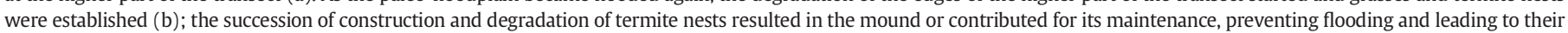

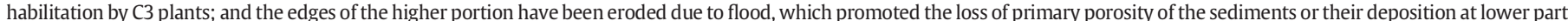

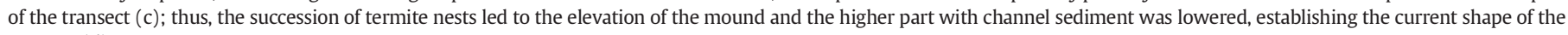
transect (d).

with fluvial fans, where avulsion usually generates the deposition of coarse sediments over fine sediments (Mackey and Bridge, 1995), it is possible that the initial formation of argillic horizons (Phillips, 2004) also is related to this dynamic of the depositional system. Nevertheless, the identification of this process along the transect is difficult because the site is strongly affected by pedogenesis, but slight differences of sand particle size distribution can be observed between E and Btg horizons.
In the mound pedon, intense clay illuviation also was detected, with fine materials filling pores and cavities constructed by termites. The high level of exchangeable sodium disperses the clay, which is transported by lateral and downward water fluxes (Kühn et al., 2010), accounting for the abundance of clay that fills pores and cavities.

As the geomorphology of the transect evolved, as described above, other pedogenic processes were initiated simultaneously, such as gleization, plinthization, eluviation, and bioturbation. Gleization was initiated 
progressively in the lower part of the transect as the base level rose, leading to a seasonal hydromorphic condition tied to Pantanal seasonal flooding. It caused iron segregation and, after several cycles, formed plinthite and petroplinthite formation (Plinthization) (Buol et al., 2011; Vepraskas, 2001), as can be seen in the macromorphology and micromorphology of the Btg of the lower part of the transect.

Due to the annual seasonal hydromorphic variations that have persisted for a long time, horizons that overlying the Btg at the lower part of the transect have been subjected to eluviation and degradation triggered by ferrolysis (Brinkman, 1970). Evidence of this process is seen in the strong acid $\mathrm{pH}$, high levels of exchangeable aluminum, low base saturation, sandy texture, and variegated color (Van Ranst and Coninck, 2002). Thus, the ferrolysis, coupled with the sand addition from the highest part of the transect due to erosion, resulted in the formation of a relatively thick $\mathrm{E}$ horizon.

The seasonal presence of water saturating and flooding the soils also favored the establishment of termites responsible for bioturbation (Oliveira-Filho, 1992). Termite nests in flooded places are continuously eroded and reconstructed, with materials added from subsurface to surface horizons (Oliveira-Filho and Furley, 1990), thereby resulting in the formation of the mound. As described above, this set of evidence can be observed in macro- and micromorphology of the mounds, as well as in their chemical attributes. Further, the fact that the mound contains more $\mathrm{C}$ and $\mathrm{N}$ than the flooded places that currently have grasses, and where the highest $\mathrm{C}$ and $\mathrm{N}$ levels are expected, corroborates the contribution of the termite activity to the humification process of the SOM of the mound (Brauman, 2000).

Exchangeable sodium accumulation (sodification process) likely is associated with climate conditions of aridity or semiaridity in the Pantanal during the Holocene (Bertaux et al., 2002; Kuerten et al., 2013; McGlue et al., 2012). However, some questions still remain, mainly because the soils of Northern Pantanal have no environmental clues that indicate the aridity and semiaridity in the past, such as enrichment in isotopic signal (Farquhar et al., 1989) and clay minerals typically formed in a drier environment or under high salt concentration (Furquim et al., 2010).

Even if the evidence of past climates is stronger, we must consider that current evapotranspiration exceeds the effective rainfall during eight months each year at this site (Sanches et al., 2010). The rainfall in the Pantanal ends with the summer (March), period when the flooding is at its maximum, which extends until June. This dynamic associated with the high evapotranspiration during this period may have concentrated sodium in the higher part of the transect and at the boundary of the flooding. It could explain the ESP levels of around 10 at the boundary of flooding (borehole AT1 and AT6). However, explaining the sodium concentration by current evapotranspiration seems improbable if the ESP value of 20 in deep layers (300 cm in borehole AT3) is considered, because it is unlikely that the evapotranspiration influenced this depth. Research is being carried out to further understand the genesis of the sodic soils in this region of the Pantanal.

\section{Conclusion}

The sediments of the transect were originated by activity of the São Lourenço fluvial fan during the Upper Pleistocene. These deposits, since their initial configuration, are being eroded, resulting in lowering of the landforms, as the levee and part of the channel. Each step of landform evolution changes the hydrology of the environment and establishes the conditions of the soil-forming processes.

Evidence of pedogenic processes in the transect includes: a) clay eluviation and illuviation, resulting in formation of the Bt horizon in the soils at the lower part of the transect and mound; b) gleization and plinthization, mainly at the lower part of the transect, resulting in formation of mottles, nodules and reduced soil matrix; c) bioturbation, responsible for addition of materials at the soil surface, resulting in the formation/maintenance of the mound; and d) sodium concentration, with the highest levels in the mounds, observed in soils that have higher clay contents.

Soil distribution and soil-forming processes identified here can be used to better understand the relationship between the soil and the landform elements of this Pleistocene lobe. Even beyond pedology, this approach is appropriate for studies seeking to better understand landform evolution, landscape dynamics, and geochemical cycles in wetlands and in the Pantanal sedimentary environment.

\section{Acknowledgments}

The authors wish to thank FAPESP for granting a PhD scholarship for the first (process 2009/50422-3) and fifth (process 2011/11905-9) authors and for the financial funds to carry out the research (process 2009/54372-0). We also thank SESC Pantanal for the logistic support and CNPq for the grants given to the sixth (process 300189/2010-9) and seventh (process 201049/2012-0) authors and for the PhD scholarship(process 200165/2008-9) granted to the fourth author.

\section{Appendix A. Supplementary data}

Supplementary data associated with this article can be found in the online version, at http://dx.doi.org/10.1016/j.geoderma.2015.04.025. These data include Google map of the most important areas described in this article.

\section{References}

Abe, S.S., Kotegawa, T., Onishi, T., Watanabe, Y., Wakatsuki, T., 2012. Soil particle accumulation in termite (Macrotermes bellicosus) mounds and the implications for soil particle dynamics in a tropical savanna Ultisol. Ecol. Res. 27, 219-227.

Assine, M.L., Silva, A., 2009. Contrasting fluvial styles of the Paraguay river in the northwestern border of the Pantanal wetland, Brazil. Geomorphology 113, 189-199.

Assine, M.L., Corradini, F.A., Pupim, F.N., McGlue, M.M., 2014. Channel arrangements and depositional styles in the São Lourenço fluvial megafan, Brazilian Pantanal wetland. Sediment. Geol. 301, 172-184.

Barros, A.M., Silva, R.H., Cardoso, O.R.F.A., Freire, F.A., Souza Junior, J.., Rivetti, M., Luz, D.S. Palmeira, R.C.B., Assinari, C.C.G., 1982. Geologia da Folha Cuiabá. In: Brasil (Ed.), Projeto RADAMBRASIL. Ministério de Minas e Energia, Rio de Janeiro, pp. 25-192.

Bertaux, J., Sondag, F., Santos, R., Soubiès, F., Causse, C., Plagnes, V., Cornec, F.L., Seidel, A., 2002. Paleoclimatic record of speleothems in a tropical region: study of laminated sequences from a Holocene stalagmite in Central-West Brazil. Quat. Int. 89, 3-16.

Black, H.I.J., Okwakol, M.J.N., 1997. Agricultural intensification, soil biodiversity and agroecosystem function in the tropics: the role of termites. Appl. Soil Ecol. 6, 37-53.

Boulet, R., 1988. Análise estrutural da cobertura pedológica e cartografia. In: Moniz, A.C. Furlani, A.M.C., Furlani, P., Freitas, S.S. (Eds.), A responsabilidade social da ciência do solo. Sociedade Brasileira de Ciência do Solo, Campinas, pp. 79-90.

Brauman, A., 2000. Effect of gut transit and mound deposit on soil organic matter transformations in the soil feeding termite: a review. Eur. J. Soil Biol. 36, 117-125.

Brinkman, R., 1970. Ferrolysis, a hydromorphic soil forming process. Geoderma 3, 199-206.

Brown, G., Brindley, G.W., 1980. X-ray diffraction procedures for clay mineral identification. In: Brindley, G.W., Brown, G. (Eds.), Crystal Structures of Clay Minerals and their X-ray Identification. Mineralogical Society, London, pp. 305-359.

Brune, A., Kühl, M., 1996. pH profiles of the extremely alkaline hind guts of soil-feeding termites (Isoptera: Termitidae) determined by micro pH electrodes. J. Insect Physiol. 42, 1121-1127.

Bullock, P., Federoff, N., Jongerius, A., Stoops, G., Tursina, T., 1985. Handbook for Soil Thin Section Description. Waine Research Publications, London.

Buol, S.W., Southard, R.J., Graham, R.C., McDaniel, P.A., 2011. Soil Genesis and Classification. sixth ed. Willey-Blackwell, Chichester.

Carvalho, J.L.N., Raucci, G.S., Cerri, C.E.P., Bernoux, M., Feigl, B.J., Wruck, F.J., Cerri, C.C. 2010. Impact of pasture, agriculture and crop-livestock systems on soil C stocks in Brazil. Soil Tillage Res. 110, 175-186.

Corradini, F.A., Assine, M.L., 2012. Compartimentação geomorfológica e processos deposicionais no megaleque fluvial do rio São Lourenço, Pantanal mato-grossense. Rev. Bras. Geosci. 42, 20-33.

Cosarinsky, M.I., 2011. The nest growth of the Neotropical mound-building termite, Cornitermes cumulans: a micromorphological analysis. J. Insect Sci. 2, 1-14.

Ellery, W.N., McCarthy, T.S., Dangerfield, J.M., 1998. Biotic factors in Mima mound development: evidence from the floodplains of the Okavango Delta, Botswana. Int. J. Ecol. Environ. Sci. 24, 293-313.

Embrapa, 1997. Manual de métodos de análise de solo. second ed. Centro Nacional de Pesquisa de Solos, Rio de Janeiro.

Farquhar, G.D., Ehleringer, R., Hubic, K.T., 1989. Carbon isotope discrimination and photosynthesis. Annu. Rev. Plant Physiol. Plant Mol. Biol. 40, 503-537. 
Farrell, K.M., 2001. Geomorphology, facies architecture, and high-resolution, non-marine sequence stratigraphy in avulsion deposits, Cumberland Marshes, Saskatchewan. Sediment. Geol. 139, 93-150.

Furquim, S.A.C., Barbiero, L., Graham, R.C., Queiroz Neto, J.P., Ferreira, R.P.D., Furian, S. 2010. Neoformation of micas in soils surrounding an alkaline-saline lake of Pantanal wetland, Brazil. Geoderma 158, 331-342.

Gee, G.W., Bauder, J.W., 1986. Particle-size analysis. In: Klute, A. (Ed.), Methods of Soil Analysis, second ed. ASA and SSSA, Madison, pp. 383-411.

Girard, P., Fantin-Cruz, I., Oliveira, S.M.L., Hamilton, S.K., 2010. Small-scale spatial variation of inundation dynamics in a floodplain of the Pantanal (Brazil). Hydrobiologia 638, 223-233.

Guo, L.B., Gifford, R.M., 2002. Soil carbon stocks and land use change: a meta analysis. Glob. Chang. Biol. 8, 345-360.

Huggett, J.M., Gale, A.S., Clauer, N., 2001. The nature and origin of non-marine 10 clay from the Late Eocene and Early Oligocene of the Isle of Wight (Hampshire Basin), UK. Clay Miner. 36, 447-464.

Jackson, M.L., 1979. Soil Chemical Analysis: Advanced Course. Madson.

Jouquet, P., Lepage, M., Velde, B., 2002. Termite soil preferences and particle selections: strategies related to ecological requirements. Insect. Soc. 49, 1-7.

Jouquet, P., Bottinelli, N., Lata, J.C., Mora, P., Caquineau, S., 2007. Role of the fungus-growing termite Pseudacanthotermes spiniger (Isoptera, Macrotermitinae) in the dynamic of clay and soil organic matter content. An experimental analysis. Geoderma 139, 127-133.

Kemp, R.A., 1999. Micromorphology of loess-paleosol sequences: a record of paleoenvironmental change. Catena 35, 179-196.

Kemp, R.A., Toms, P.S., King, M., Kröhling, D.M., 2004. The pedosedimentary evolution and chronology of Tortugas, a Late Quaternary type-site of the northern Pampa, Argentina. Quat. Int. 114, 101-112.

Kemp, R.A., Zárate, M., Toms, P., King, M., Sanabria, J., Arguello, G., 2006. Late Quaternary paleosols, stratigraphy and landscape evolution in the Northern Pampa, Argentina. Quat. Res. 66, 119-132.

Kooistra, M.J., Pulleman, M.M., 2010. Features related to faunal activity. In: Stoops, G., Marcelino, V., Mees, F. (Eds.), Interpretation of Micromorphological Features of Foils and Regoliths. Elsevier, Amsterdam, pp. 397-418.

Kuerten, S., Parolin, M., Assine, M.L., McGlue, M.M., 2013. Sponge spicules indicate Holocene environmental changes on the Nabileque River floodplain, southern Pantanal, Brazil. J. Paleolimnol. 49, 171-183.

Kühn, P., Terhorst, B., Ottner, F., 2006. Micromorphology of middle Pleistocene paleosols in northern Italy. Quat. Int. 156-157, 156-166.

Kühn, P., Aguilar, J., Miedema, R., 2010. Textural pedofeatures and related horizons. In: Stoops, G., Marcelino, V., Mees, F. (Eds.), Interpretation of Micromorphological Features of Soils and Regoliths. Elsevier, Amsterdam, pp. 217-250.

Lal, R., 1988. Effects of macrofauna on soil properties in tropical systems. Agric. Ecosyst. Environ. 24, 101-116.

Lee, K.E., Wood, T.G., 1971. Termites and Soils. Academic Press, New York.

Léonard, J., Rajot, J., 2001. Influence of termites on runoff and infiltration: quantification and analysis. Geoderma 104, 17-40.

Mackey, S.D., Bridge, J.S., 1995. Three-dimensional model of alluvial stratigraphy: theory and application. J. Sediment. Res. 65, 7-31.

Mason, J.A., Joeckel, R.M., Bettis, E.A., 2007. Middle to Late Pleistocene loess record in eastern Nebraska, USA, and implications for the unique nature of Oxygen Isotope Stage 2. Quat. Sci. Rev. 26, 773-792.

McCarthy, T.S., Ellery, W.N., Dangerfield, J.M., 1998. The role of biota in the initiation and growth of island on the floodplain of the Okavango alluvial fan, Botswana. Earth Surf. Process. Landf. 33, 291-316.

McGlue, M.M., Silva, A., Zani, H., Corradini, F.A., Parolin, M., Abel, E.J., Cohen, A.S., Assine, M.L., Trees, M.A., Kuerten, S., Gradella, F.G., Rasbold, G.G., 2012. Lacustrine records of Holocene flood pulse dynamics in the Upper Paraguay River watershed (Pantanal wetlands, Brazil). Quat. Res. 78, 285-294.

Mermut, A.R., Arshad, M.A., Arnaud, R.J.S., 1984. Micropedological study of termite mounds of three species of Macrotermes in Kenia. Soil Sci. Soc. Am. J. 48, 613-620.

Miedema, R., Brouwer, J., Geiger, S.C., Vandenbeldt, R.J., 1994. Variability in the growth of Faidherbia albida near Niamey, Niger, Africa: micromorphological aspects of the termite activity. In: Ringrose-Voase, A.J., Humpheys, G.S. (Eds.), Soil Micromorphology: Studies in Management and Genesis. Developments in Soil Science. Elsevier, pp. 411-419.

Moore, D.M., Reynolds Jr., R.C., 1989. X-ray Diffraction and the Identification and Analysis of Clay Minerals. Oxford University press, New York.
Mujinya, B.B., Mees, F., Erens, H., Dumon, M., Baert, G., Boeckx, P., Ngongo, M., Van Ranst, E., 2013. Clay composition and properties in termite mounds of the Lubumbashi area, D.R. Congo. Geoderma 192, 304-315.

Murphy, C.P., 1986. Thin Section Preparation of Soils and Sediments. Academic Publis. Berkhanmsterd.

Murray, A.S., Wintle, A.G., 2000. Luminescence dating of quartz using an improved singlealiquot regenerative-dose protocol. Radiat. Meas. 33, 57-73.

Nascimento, A.F., 2012. Relationships Pedology-Geomorphology-Sedimentology in the Pantanal North (Only Abstract in English). (PhD These), Escola Superior de Agricultura Luiz de Queiroz - Universidade de São Paulo, Piracicaba (Available in: http://www. teses.usp.br/teses/disponiveis/11/11140/tde-06072012-103745/en.php).

Nichols, G., 2009. Sedimentology and Stratigraphy. second ed. Wiley-Blackwell, United Kingdom.

Nichols, G.J., Fisher, J.A., 2007. Processes, facies and architecture of fluvial distributary system deposits. Sediment. Geol. 195, 75-90.

Oliveira-Filho, A.T., 1992. Floodplain "Murundus" of Central Brazil: evidence for the termite-origin hypothesis. J. Trop. Ecol. 8, 1-19.

Oliveira-Filho, A.T., Furley, P.A., 1990. Monchão, Cocoruto, Murundu. Ciênc. Hoje 11, 30-37.

Phillips, J.D., 2004. Geogenesis, pedogenesis, and multiple causality in the formation of texture-contrast soils. Catena 58, 275-295.

Renard, D., Birk, J.J., Glaser, B., Iriarte, J., Grisard, G., Karl, J., McKey, D., 2012. Origin of mound-field landscape: a multy-proxy approach combining contemporary vegetation, carbon stable, isotopes and phytoliths. Plant Soil 351, 337-353.

Sallun, A.E.M., Suguio, K., Tatumi, S.H., Yee, M., Santos, J., Barreto, A.M.F., 2007. Datação absoluta de depósitos quaternários brasileiros por luminescência. Rev. Bras. Geosci. 37, 402-413.

Sanches, L., Alves, M.C., Campelo Júnior, J.H., Nogueira, J.S., Dalmagro, H.J., 2010. Estimativa do coeficiente Priestley-Taylor em floresta monodominante cambarazal no Pantanal. Rev. Bras. Meteorol. 25, 448-454.

Sarcinelli, T.S., Schaefer, C.E.G.R., Lynch, L.D.S., Arato, H.D., Viana, J.H.M., Filho, M.R.D.A. Gonçalves, T.T., 2009. Chemical, physical and micromorphological properties of termite mounds and adjacent soils along a toposequence in Zona da Mata, Minas Gerais State, Brazil. Catena 76, 107-113.

Schaefer, C.E.R., 2001. Brazilian Latosols and their B horizon microstructure as long-term biotic constructs. Aust. J. Soil Res. 39, 909-926.

Schoeneberger, P.J., Wysocki, D.A., Benham, E.C., 2002. Field book for describing and sampling soils, version 2.0. Natural Resources Conservation Service, National Soil Survey Center, Lincoln.

Silva, L.C.R., Vale, G.D., Haidar, R.F., Sternberg, L.S.L., 2010. Deciphering earth mound origins in central Brazil. Plant Soil 336, 3-14.

Slingerland, R., Smith, N.D., 1998. Necessary conditions for a meandering-river avulsion. Geology 26, 435-438.

Soil Survey Staff, 2014. Keys to Soil Taxonomy. 12th ed. USDA-Natural Resources Conservation Service, Washington.

Srodón, J., Eberl, D.D., 1984. Illite. In: Bailey, S.W. (Ed.), Micas: Reviews in Mineralogy. Mineralogical Society of America, Washington, pp. 495-544.

Van Breemen, N., Buurman, P., 2002. Soil Formation. second ed. Kluwer Academic Publishers, Dordrecht.

Van der Meer, J.J.M., Menzies, J., 2011. The micromorphology of unconsolidated sediments. Sediment. Geol. 238, 213-232.

Van Ranst, E., Coninck, F., 2002. Evaluation of ferrolysis in soil formation. Eur. J. Soil Sci. 53 513-519.

Vepraskas, M.J., 2001. Morphological features of seasonally reduced soils. In: Richardson, J.L., Vepreaskas, M.L. (Eds.), Wetland Soils: Genesis, Hydrology, Landscapes, and Classification. Lewis, Boca Raton, pp. 163-182.

Winter, T.C., 2000. The vulnerability of wetlands to climate change: a hydrologic landscape perspective. J. Am. Water Resour. Assoc. 36, 305-311.

Zech, W., Zech, M., Zech, R., Peinemann, N., Morrás, H.J.M., Morettid, L., Ogle, N., Kalim R.M., Fuchs, M., Schad, P., Glaser, B., 2009. Late Quaternary paleosol records from subtropical $\left(38^{\circ} \mathrm{S}\right)$ to tropical $\left(16^{\circ} \mathrm{S}\right)$ South America and palaeoclimatic implications. Quat. Int. 196, 107-120.

Zinn, Y.L., Lal, R., Resck, D.V.S., 2005. Texture and organic carbon relations described by a profile pedotransfer function for Brazilian Cerrado soils. Geoderma 127, 168-173. 